\title{
Exploring corporate social responsibility and financial performance through stakeholder theory in the tourism industries
}

DOI:

10.1016/j.tourman.2017.03.018

\section{Document Version}

Accepted author manuscript

Link to publication record in Manchester Research Explorer

Citation for published version (APA):

Theodoulidis, B., Diaz, D., Crotto, F., \& Rancati, E. (2017). Exploring corporate social responsibility and financial performance through stakeholder theory in the tourism industries. Tourism Management, 62, 173-188.

https://doi.org/10.1016/j.tourman.2017.03.018

\section{Published in:}

Tourism Management

\section{Citing this paper}

Please note that where the full-text provided on Manchester Research Explorer is the Author Accepted Manuscript or Proof version this may differ from the final Published version. If citing, it is advised that you check and use the publisher's definitive version.

\section{General rights}

Copyright and moral rights for the publications made accessible in the Research Explorer are retained by the authors and/or other copyright owners and it is a condition of accessing publications that users recognise and abide by the legal requirements associated with these rights.

\section{Takedown policy}

If you believe that this document breaches copyright please refer to the University of Manchester's Takedown Procedures [http://man.ac.uk/04Y6Bo] or contact uml.scholarlycommunications@manchester.ac.uk providing relevant details, so we can investigate your claim.

\section{OPEN ACCESS}




\title{
Exploring corporate social responsibility and financial performance through stakeholder theory in the tourism industries
}

\begin{abstract}
The literature examining the relationship between corporate social responsibility (CSR) and corporate financial performance (CFP) in the tourism industries is extensive but it has not verified the relationship unambiguously. This has been attributed to the methodological artefacts used, but also to the lack of a solid theoretical foundation. Based on stakeholder theory, this paper proposes the use of two models that explicitly investigate the relationship between stakeholder management, expressed as CSR activities, firm strategy and CFP. The strategic stakeholder model and the intrinsic stakeholder commitment model are evaluated in terms of their descriptive accuracy in four different tourism-related industries (airlines, casinos, hotels and restaurants) using panel regressions for the years 2005 to 2014. The results provide useful theoretical insights into the way in which CSR interacts with firm strategy and CFP, as well as managerial insights into how tourism practitioners can identify which CSR activities may impact CFP.
\end{abstract}

Keywords: corporate social responsibility, financial performance, stakeholder theory, tourism industry, airlines, casinos, hotels, restaurants 


\section{Introduction}

Stakeholder interests are posited as being critical to the success of any business, according to the managerial literature (Freeman 1984; Falck \& Heblich 2007; Berman et al. 1999). In particular, it has been argued that managers should directly and explicitly take into consideration stakeholders' interests and needs, and aim to address them through different aspects of the firm's strategy (Falck \& Heblich 2007). Central to the interests of the various stakeholders is the social performance of the firm, assessed through corporate social responsibility (CSR) activities, such as those captured by the MSCI ESG data set (previously known as the KLD data set) (MSCI 2015a), a popular source that has been widely used in previous work.

The literature examining the relationship between CSR and corporate financial performance (CFP) is extensive but it has not verified the relationship unambiguously. A number of comparative studies have been carried out to examine the CSR-CFP relationship in order to understand the reasons behind the mixed results, to identify the determinants of the relationship and to highlight gaps and opportunities for further research. These comparative studies employed narrative reviews (Ambec \& Lanoie 2008; Coles et al. 2013), vote-counting (Margolis et al. 2009) or meta-analysis (Allouche \& Laroche 2005; Endrikat et al. 2014; Albertini 2013; Dixon-Fowler et al. 2013; Orlitzky et al. 2003).

Despite the increased interest, the relationship "has not yet been unequivocally verified through empirical studies" (Coles et al. 2013). This has been attributed, in part, to the different and not directly comparable methodological artefacts used, for instance, empirical methods, CSR and CFP dimensions, data sets, multi-industry/cross-sectional perspective and organisational culture, but also to the lack of a solid theoretical foundation (Coles et al., 2013; Endrikat et al., 2014; Lee, 2008; Orlitzky et al., 2003).

In addition, recent literature has highlighted the need to study different industries and sectors separately (Endrikat et al. 2014). It has been reasoned that each industry faces unique challenges in relation to their internal and external environment, such as different levels of competition, varied stakeholder interests, and different regulatory contexts and market conditions, among others, which create various pressures and requirements for their 
involvement with CSR activities and their effect on CFP (Griffin \& Mahon 1997; Godfrey \& Hatch 2007; Endrikat et al. 2014; Russo \& Fouts 1997; Busch \& Hoffmann 2011).

In this paper we study the CSR-CFP relationship in the tourism-related industries. The tourism sector includes all those organisations that are designed to "serve the specific needs and wants of tourists" (Leiper 1979). Tourism-related industries can be divided into six different segments, namely, tourist carriers (e.g. airlines), tourist attractions (e.g. casinos), tourist accommodation (e.g. hotels), tourist services (e.g. restaurants), tourism marketing (e.g. national tourism bodies) and tourism regulators (e.g. governmental organisations) (Leiper 1979). For the purposes of this work, we examine the first four, since they mainly consist of private organisations (Inoue \& Lee 2011; Kang et al. 2010).

In relation to the theoretical foundations, tourism-related literature has not fully considered the possible interaction or moderation effects of firm, industry, strategy and operating environment variables, as these have been addressed in manufacturing firms (Berman et al. 1999). Recent tourism-related studies have recognised the need to investigate interaction or moderation models and have considered moderators such as oil prices (Lee, Seo et al., 2013), economic conditions (Lee, Singal et al., 2013), market dynamism (Leonidou et al. 2013), competitive intensity (Leonidou et al. 2013) and firm size (Youn et al. 2015). However, these have been studied without a common theoretical framework that could justify their relevance.

In order to close this gap, we propose the use of the stakeholder theory as the theoretical viewpoint that could facilitate an understanding of the relationship between CFP and CSR activities in the tourism-related industries, as well as rationalise the possible interaction or moderation effects of firm, industry, strategy and operating environment variables. Taking into consideration the strategic stakeholder and the intrinsic stakeholder commitment models (Berman et al. 1999), we provide a strong theoretical foundation in order to examine the relationship between CSR and CFP for the tourism sector and its industries.

In this paper we contribute to the literature in four key areas. First, we contribute to the theoretical foundations of tourism-related research by proposing the use of two models that explicitly investigate the relationship between stakeholder management, expressed as CSR activities, firm strategy and CFP. The two models, namely, the strategic stakeholder model and the intrinsic stakeholder commitment model (Berman et al. 1999), provide a theoretical foundation that is rooted in the stakeholder theory (Freeman 1984). Second, we contribute 
to the empirical research on the tourism sector by evaluating the descriptive accuracy of the proposed models and by providing useful insights into the efficacy of stakeholder management practices, expressed as CSR activities. Third, we contribute to the empirical research in four different tourism-related industries, namely, airlines, casinos, hotels and restaurants, by providing insights into the way that stakeholder management practices, expressed as CSR activities, interact with firm strategy and CFP. Finally, we propose sound methodological artefacts so that our study is both replicable and comparable to related studies (Hartshorne \& Schachner 2012; Endrikat et al. 2014).

In summary, this research contributes to the body of tourism-related literature by addressing the lack of a theoretical foundation and by providing empirical evidence through the application of the proposed research model to a long-term industry-specific investigation using multidimensional CSR measures in panel data. Furthermore, the study provides tourism managers in the selected industries (airlines, casinos, hotels and restaurants) with clear understandings about which CSR activity areas would impact the firm's financial performance.

\section{Literature Review}

As argued by Coles et al. (2013), in order for tourism-related research to progress further, "greater critical engagement with mainstream thinking on CSR is required as well as greater conceptual and methodological sophistication". This implies that tourism-related research needs to examine theoretical frameworks and models that have been used to examine the CSR-CFP relationship in other sectors and, furthermore, to explore more sophisticated empirical methods. In this section, we discuss stakeholder theory and its relevance to CSR. We also critically review tourism-related CSR-CFP studies and we argue that stakeholder theory can provide a suitable theoretical framework to examine this relationship.

\subsection{Stakeholder Theory}

According to Freeman (1984), the stakeholder theory identifies the generation of value as a central driver of the enterprise, but it also recognises that this value is to be shared by a group of stakeholders that includes not only shareholders and managers but also all actors in society that may have an interest in how the firm operates. The theory is organised under two principal questions: What is the purpose of the firm? And what responsibility does 
management have to stakeholders? These questions direct executives to think about how they want to pursue business, and what kind of relationships - and with what emphasis they want and need to create with interest groups (stakeholders) in order to achieve their goals (Freeman 2000).

The stakeholder theory is "managerial" in the sense that it addresses how managers perform their duties, and it is intimately connected to the practice of business, of value creation and trade (Laplume et al. 2008). Moreover, it explicitly recognises that shareholders are important stakeholders; however, they are just one of myriad incumbents. Similarly, it recognises that profits are a critical dimension of the day-to-day activity of the firm, but profits and financial performance are one possible outcome of the process of value creation.

According to Donaldson and Preston (1995), the theory can be examined from three different perspectives, namely, the descriptive, instrumental and normative perspectives. The descriptive perspective assumes an empirically oriented use of the theory to show how concepts correspond to reality. The instrumental perspective relates to the use of the theory to show the connection between stakeholder management and multi-dimensional corporate performance. Finally, the normative perspective is used to examine how stakeholders should behave and the motivations underlying their actions.

The interest in stakeholder theory started from the field of strategic management (e.g. Clarkson, 1995), and then grew into organisation theory (e.g. Donaldson \& Preston, 1995) and business ethics (e.g. Phillips \& Reichart, 2000), social issues in management (e.g. Wood, 1991), and sustainable development (e.g. Sharma \& Henriques, 2005). Over the last few years, there has been a rise in its prominence and, in a recent review by Laplume et al. (2008), the literature on stakeholder theory addressed five themes across multiple research fields, namely, stakeholder definition and salience, stakeholder actions and responses, firm actions and responses, firm performance and theory debates.

\subsection{Stakeholder Theory and CSR}

CSR is seen as "a process to integrate social, environmental, ethical, human rights and consumer concerns into their business operations [...] with the aim of maximizing the creation of shared value for their owners/shareholders and for their other stakeholders and society at large" (European Commission 2011). This conceptualisation of CSR fits nicely with the stakeholder theory approach that views CSR as an extension of corporate 
governance, whereby a firm's duties extend beyond its shareholders to a broader group of stakeholders (Freeman 1984; Donaldson \& Preston 1995; Rowley \& Berman 2000).

While previous empirical research viewed CSR activities under a single aggregated measure, there is a strong view that the different dimensions of CSR affect the firm in different ways and, thus, should be examined separately (Inoue \& Lee 2011). Furthermore, it has been argued that the multidimensionality of CSR can be better assessed through a stakeholder framework that evaluates how firms manage their relationships with their stakeholders (Clarkson 1995; Rowley \& Berman 2000).

In this paper we argue that tourism-related research has adopted research models that did not explicitly consider the stakeholder influence on firm strategy and, more specifically, have not considered the possible interaction or moderation effects of firm, industry and operating environment variables, as these have been addressed in other sectors, such as manufacturing (Berman et al., 1999).

The stakeholder theory can be used with three different perspectives to study how stakeholder interests affect the characteristics of the firm and its multi-dimensional performance, namely, descriptive (how the stakeholder theory concepts correspond to reality), instrumental (what are the configurations of managers' decisions regarding stakeholder interest in CSR activities and the outcomes?) and normative (how managers should deal with stakeholders' concerns regarding CSR activities and their motivations for it) (Donaldson \& Preston 1995). The conceptualisation of these perspectives requires development of the appropriate research models.

From the instrumental and normative perspectives, and drawing upon the wider management literature, Berman et al. (1999) proposed the stakeholder management model and its two types: the direct effects model and the moderated model. The direct effects model considers the relationship between CSR and CFP to be independent from the relationship between firm strategy and CFP, assuming that stakeholder management is not taken into consideration in the formulation of the firm's strategy (Hambrick 1983). The moderated model considers that stakeholder management and the corresponding CSR activities moderate the relationship between firm strategy and CFP, assuming that CSR could affect the relationship but is not a driver for it. In other words, firm strategy might take stakeholder interests into consideration, as long as these are in line with shareholder interests. From the normative perspective, Berman et al. (1999) proposed the intrinsic 
stakeholder commitment model, whereby stakeholder interests and the corresponding CSR activities affect the relationship between firm strategy and CFP and they are explicitly taken into consideration in the formulation of the firm's decision-making. Under this model, CSR intermediates the relationship. In all three models, the wider environmental conditions for the specific industry are captured with operating environment variables that are defined at industry level and help to isolate their effects on CFP (Jauch \& Kraft 1986). Overall, the conceptualisation proposed by Berman et al. (1999) allows isolation of the effects of stakeholder relationships, expressed as CSR activities, on CFP after including measures of firm strategy and controlling for the operating environment.

\subsection{CSR and CFP in the Tourism Literature}

Research examining CSR in the tourism sector has appeared over the last 20 years in many specialist journals (Sainaghi et al. 2017). In addition to studying the relationship between CSR and CFP, the previous literature also looked at CSR in sustainable tourism, consumer trust, consumer perceptions and attitudes towards CSR practice in tourism firms (Dabic et al. 2016). It also investigated the relationship between CSR and a broader performance measurement perspective than simply financial performance (Mohammed et al. 2015; Phillips \& Moutinho 2014; Sainaghi et al. 2017). A summary of the previous CSR-CFP studies on tourism-related industries is shown in Table 1.

Lee and Park (2009a) explored the CSR-CFP relationship in casinos and hotels using an aggregated CSR measure from the MSCI ESG data set. The research model assumed that there is a relationship between CSR and CFP in terms of return-on-assets (ROA), returnon-equity (ROE) and average market value (AMV), and two firm-level measures (firm size and leverage) were used as controls.

Lee and Park (2009b) explored the CSR-CFP relationship in airlines using an aggregated CSR measure from the MSCI ESG data set and its quadratic $\left(\mathrm{CSR}^{2}\right)$ and cubic $\left(\mathrm{CSR}^{3}\right)$ values to capture the degree of the firm's practice. The research model assumed that there is a relationship between CSR and CFP in terms of ROA, ROE, AMV, return on sales (ROS) and excess market value (EMV), and two firm-level measures (firm size and leverage) were used as controls.

Molina-Azorin et al. (2009) explored the CSR-CFP relationship in Spanish hotels using data collected through questionnaires. They used 12 CSR measures divided into 2 types: basic environmental commitment (purchase of ecological products, environmental 
collaboration with the customer, the use of environmentally dangerous products, energysaving practices, water-saving practices and collection of solid residues); and advanced environmental commitment (employee training in environmental matters, compensation for employees for environmental initiatives, the use of ecological arguments in marketing campaigns, organisation of environmental activities by the firm, long-term environmental approach, quantification of environmental savings and costs). They assumed a direct effects model for the relationship between CSR and CFP. CFP was examined in terms of the occupancy rate per room (ORR), gross operative profit (GOP) and GOP per available room per day (GOPPAR per day), as these are considered to be more appropriate measures of financial performance for the hotel industry. In addition, they examined the relationship between CSR and competitive performance, measured as market share gain and sales growth, and stakeholder satisfaction, measured as an aggregate of customer and employee satisfaction.

Kang et al. (2010) provided one of the earliest efforts to explore the CSR-CFP relationship in four tourism-related industries (airlines, casinos, hotels, restaurants) using two aggregated CSR measures based on the positive (CSRpos) and negative (CSRneg) key issues from the MSCI ESG data set. They assumed a direct effects model for the relationship between CSR and CFP, and two firm-level measures (firm size and leverage) and one industry-level measure (average monthly S\&P500 index (MARKET)) were used as controls. CFP was examined in terms of both short-term (ROA and ROE) and long-term profitability (Tobin's Q and price-per-earnings (PER)).

Inoue and Lee (2011) explored the CSR-CFP relationship in four tourism-related industries (airlines, casinos, hotels, restaurants), addressing the multidimensionality of CSR using data from five themes of the MSCI ESG data set, namely, community (COM), diversity (DIV), employee relations (EMP), environmental performance (ENV) and product safety/quality (PRO) (MSCI 2015b). The research model assumed that there is a relationship between CSR and CFP in terms of both short-term (ROA and neoclassical economic view) and long-term profitability (Tobin's Q and resource-based view), and two firm-level measures (firm size and leverage) were used as controls.

Lee, Singal et al. (2013) explored the CSR-CFP relationship in US restaurants using two aggregated CSR measures from the MSCI ESG data set. The CSR measures were operations-related (OR) and non-operations-related (non-OR), depending on whether or not they were related to the firm's core operations. Specifically, the aggregated measure for 
OR was calculated based on three MSCI ESG themes (employee relations, product and corporate governance). They assumed a moderated model for the relationship between CSR and CFP, with economic conditions (recession (REC)) as the moderator variable. They examined CFP in terms of long-term profitability (Tobin's Q). The controls used were five firm-level measures (firm size, leverage, ROA, systematic risk (BETA) and dividend payout per share (DIV)) and one industry-level measure (recession (REC)).

Lee, Seo et al. (2013) explored the CSR-CFP relationship in airlines. Two aggregated CSR measures were used: operations-related (OR) and non-operations-related (non-OR). They assumed a moderated model for the relationship between CSR and CFP, with oil prices (OIL) as the moderator variable. The controls used were four firm-level measures (firm size, leverage, ROA, DIV) and one country-level measure (gross domestic product (GDP)).

Leonidou et al. (2013) explored the CSR-CFP relationship in Greek hotels using data collected through questionnaires. The research model used was a moderated model with two moderator measures (market dynamism (MAD) and competitive intensity (CMI)). Financial performance (FIP) is measured through eight variables that relate to short-term financial performance, namely, operating profits, profit to sales ratio, profit return on investment, ROA, market share, sales volume, sales return on investment and cash flow. Environmental marketing strategy (EMS) is the CSR measure that comprises 28 binary variables and they have captured variables related to firm strategy (called competitive advantage) that include: physical resources (PHR), financial resources (FIR), experiential resources (EXR), shared vision capability (SHV), relationship-building capability (REB) and technology sensing/response capability (TSR). Overall, the research model integrates the drivers and outcomes of EMS and examines the relationship between EMS, firm strategy (competitive advantage) and CFP, which follows the intrinsic stakeholder commitment model proposed by Berman et al. (1999). Finally, this was arguably the first effort to examine the tourism industry by breaking down CSR into a number of industryspecific operational variables (Rowley \& Berman 2000).

Singal (2014) explored both the CSR-CFP and CFP-CSR relationships in tourism-related firms using aggregated measures for positive and negative CSR activities, in addition to an overall aggregated CSR measure from the MSCI ESG data set. He distinguished between family and non-family firms and assumed a direct effects model for both directions of the relationship between CSR and CFP. CFP was examined in terms of the credit rating of the firm broken down into investment grade (INVGRADE) and non-investment grade rating 
(RATING). Three firm-level measures (firm size, ownership and stock performance (STOCKRETURN)) were used as controls.

Kim and Kim (2014) explored the CSR-CFP relationship for restaurants using aggregated measures for positive and negative CSR activities, in addition to an overall aggregated CSR measure from the MSCI ESG data set. A direct effects model was assumed and CFP examined in terms of Tobin's Q and systemic risk (SR), and three firm-level measures (firm size, ROA and leverage) were used as controls.

Finally, Youn et al. (2015) explored the CSR-CFP relationship in US restaurants using two aggregated measures for positive and negative CSR activities, in addition to an overall aggregated CSR measure from the MSCI ESG data set. CFP was examined in terms of long-term profitability (Tobin's Q). They assumed a moderated model for the relationship between CSR and CFP, with firm size as the moderator variable, and the controls used were four firm-level measures (leverage, BETA, profitability (PROFIT) and degree of franchising (DOF)).

In addition to the above, a number of related studies of the hotel industry have used a direct effects model and qualitative data collected for the purposes of the research, using either surveys or questionnaires (Kirk 1995; Rodriguez \& Cruz 2007; Nicolau 2008; ClaverCortés et al. 2007; Carmona-Moreno et al. 2004; Garay \& Font 2012).

As can be seen in Table 1, under the column stakeholder theory perspectives, according to our interpretation, previous studies have considered the instrumental perspective (Donaldson \& Preston 1995); this is explicitly discussed by only two of the previous studies, namely, Inoue and Lee (2011) and Leonidou et al. (2013). In addition, it can be argued that Molina-Azorin et al. (2009) also adopt the descriptive perspective because they consider the impact of CSR activities on stakeholder satisfaction, specifically internal stakeholders (employees) and external stakeholders (customers). In summary, the previous studies do not explicitly consider a theoretical framework that relates to the three different perspectives and, thus, they limit themselves to the instrumental perspective. 


\begin{tabular}{|c|c|c|c|c|c|c|c|}
\hline Reference & $\begin{array}{l}\text { Research } \\
\text { Model }\end{array}$ & $\begin{array}{l}\text { Dependent } \\
\text { Variables }\end{array}$ & CSR & $\begin{array}{c}\text { Firm } \\
\text { Strategy }\end{array}$ & Control Variables & Statistical Model & $\begin{array}{c}\text { Stakeholder } \\
\text { Theory } \\
\text { Perspectives }\end{array}$ \\
\hline Lee and Park (2009a) & $\begin{array}{l}\text { Direct } \\
\text { Effects }\end{array}$ & $\begin{array}{l}\text { AMV, ROA, } \\
\text { ROE }\end{array}$ & CSR & & $\begin{array}{l}\text { Firm size, Leverage, } \\
\text { Year }\end{array}$ & $\begin{array}{l}\text { Regression } \\
\text { analysis }\end{array}$ & Instrumental* \\
\hline Lee and Park (2009b) & $\begin{array}{l}\text { Direct } \\
\text { Effects }\end{array}$ & $\begin{array}{l}\text { ROA, ROE, } \\
\text { ROS, AMV, } \\
\text { EMV }\end{array}$ & $\begin{array}{l}\mathrm{CSR}, \mathrm{CSR}^{2}, \\
\mathrm{CSR}^{3}\end{array}$ & & $\begin{array}{l}\text { Firm size, Leverage, } \\
\text { Year }\end{array}$ & $\begin{array}{l}\text { Regression } \\
\text { analysis }\end{array}$ & Instrumental* \\
\hline $\begin{array}{l}\text { Molina-Azorin et al. } \\
(2009)\end{array}$ & $\begin{array}{l}\text { Direct } \\
\text { Effects }\end{array}$ & $\begin{array}{c}\text { ORR, GOP, } \\
\text { GOPPAR }\end{array}$ & $\begin{array}{c}\text { basicCSR, } \\
\text { advancedCSR }\end{array}$ & & & Cluster analysis & $\begin{array}{c}\text { Descriptive* } \\
\text { Instrumental* }\end{array}$ \\
\hline Kang et al. (2010) & $\begin{array}{l}\text { Direct } \\
\text { Effects }\end{array}$ & $\begin{array}{c}\text { ROA, ROE, } \\
\text { Tobin's Q, PER }\end{array}$ & $\begin{array}{l}\text { CSRpos, } \\
\text { CSRneg }\end{array}$ & & $\begin{array}{l}\text { Firm size, Leverage, } \\
\text { MARKET }\end{array}$ & $\begin{array}{c}\text { Pooled linear } \\
\text { Regression analysis }\end{array}$ & Instrumental* \\
\hline Inoue and Lee (2011) & $\begin{array}{l}\text { Direct } \\
\text { Effects }\end{array}$ & $\begin{array}{c}\text { ROA, Tobin's } \\
\text { Q }\end{array}$ & $\begin{array}{l}\text { COM, DIV, } \\
\text { EMP, ENV, } \\
\text { PRO }\end{array}$ & & $\begin{array}{l}\text { Firm size, Leverage, } \\
\text { Year }\end{array}$ & $\begin{array}{l}\text { Regression } \\
\text { analysis }\end{array}$ & Instrumental \\
\hline Lee, Singal et al. (2013) & $\begin{array}{l}\text { Moderation } \\
(\text { REC })\end{array}$ & Tobin's Q & OR, non-OR & & $\begin{array}{l}\text { Firm size, Leverage, } \\
\text { ROA, BETA, DIV } \\
\end{array}$ & $\begin{array}{c}\text { Regression } \\
\text { analysis }\end{array}$ & Instrumental* \\
\hline Lee, Seo et al. (2013) & $\begin{array}{l}\text { Moderation } \\
\text { (OIL) }\end{array}$ & Tobin's Q & OR, non-OR & & $\begin{array}{l}\text { Firm size, Leverage, } \\
\text { ROA, DIV, GDP }\end{array}$ & Panel analysis & Instrumental* \\
\hline Leonidou et al. (2013) & $\begin{array}{c}\text { Moderation } \\
\text { (MAD, } \\
\text { CMI) }\end{array}$ & FIP & EMS & $\begin{array}{l}\text { PHR, FIR, } \\
\text { EXR, } \\
\text { SHV, } \\
\text { REB, TSR }\end{array}$ & & $\begin{array}{l}\text { Structural equation } \\
\text { modeling }\end{array}$ & Instrumental \\
\hline Singal (2014) & $\begin{array}{l}\text { Direct } \\
\text { Effects }\end{array}$ & $\begin{array}{l}\text { CSR, CSRpos, } \\
\text { CSRneg }\end{array}$ & $\begin{array}{c}\text { Family firms, } \\
\text { INVGRADE, } \\
\text { RATING } \\
\end{array}$ & & $\begin{array}{l}\text { Firm size, } \\
\text { Ownership, } \\
\text { STOCKRETURN } \\
\end{array}$ & $\begin{array}{c}\text { Regression } \\
\text { analysis, Causality } \\
\text { Test } \\
\end{array}$ & Instrumental* \\
\hline Kim and Kim (2014) & $\begin{array}{l}\text { Direct } \\
\text { Effects }\end{array}$ & Tobin's Q, SR & $\begin{array}{c}\text { CSR, } \\
\text { CSRpos, } \\
\text { CSRneg } \\
\end{array}$ & & $\begin{array}{l}\text { Firm size, Leverage, } \\
\text { ROA, Year }\end{array}$ & $\begin{array}{l}\text { Regression } \\
\text { analysis }\end{array}$ & Instrumental* \\
\hline Youn et al. (2015) & $\begin{array}{c}\text { Moderation } \\
\text { (FIRM } \\
\text { SIZE) } \\
\end{array}$ & Tobin's Q & $\begin{array}{c}\text { CSR, } \\
\text { CSRpos, } \\
\text { CSRneg } \\
\end{array}$ & & $\begin{array}{l}\text { Leverage, BETA, } \\
\text { PROFIT, DOF }\end{array}$ & Panel analysis & Instrumental* \\
\hline
\end{tabular}

*this is the authors' interpretation

Table 1: Literature Review Summary 
Furthermore, as can be seen in Table 1, previous CSR-CFP studies on tourism-related industries have used different research models to investigate the relationship and have not considered firm strategy to be part of the research model, with the exception of Leonidou et al. (2013). Moreover, they have only recently begun to investigate the moderating effects of firm characteristics, such as firm size (Youn et al. 2015), and wider sector characteristics, such as oil prices (Lee, Seo et al., 2013), economic conditions (Lee, Singal et al., 2013), market dynamism (Leonidou et al. 2013) and competitive intensity (Leonidou et al. 2013).

In relation to the statistical models used in previous studies, as can be seen in Table 1, the majority of the tourism-related studies examining the relationship between CSR and CFP have employed regression analysis and only recently started to use other models, such as structural equations (Leonidou et al. 2013) and panel regressions (Lee, Seo et al., 2013; Youn et al., 2015).

\section{Theoretical Framework}

CSR relates to activities that firms perform either voluntarily, to further some social good, or to meet legal requirements (McWilliams \& Siegel 2001). While most of the previous empirical research viewed these activities under a single aggregated measure, there is a strong view that the different dimensions of CSR affect the firm differently and, thus, should be examined separately. Furthermore, it has been argued, through longitudinal analysis, that the multidimensionality of CSR can be better assessed through a stakeholder framework that evaluates how firms manage their relationships with their stakeholders (Clarkson 1995).

In this paper we propose the adaptation of the stakeholder management models presented by Berman et al. (1999) in order to address the lack of a theoretical framework to examine the relationship between CSR and CFP in tourism-related industries. Furthermore, as a result of the multidimensionality of CSR, and the fact that each of the CSR dimensions represents activities that are relevant to different stakeholders (Clarkson 1995), we focus on five major stakeholder management activity areas that relate to environmental and social performance and which are important for the firm's operations, namely, employee relations, product-related activities, community involvement, diversity and environmental performance (MSCI 2015b). In relation to firm strategy, we follow Berman et al. (1999), 
and use measurement constructs that capture the cost leadership and differentiation dimensions that have been widely used in the managerial literature, originally proposed by Hambrick (1983).

Regarding CFP, we extend the work of Berman et al. (1999) by considering the impact of stakeholder management activities relating to CSR on market evaluation for future profitability (Tobin's Q), in addition to short-term profitability (ROA). Accounting-based performance measures, such as ROA, represent management efficiency and provide direct information regarding how certain resource allocations allow the firm to obtain its current profits (Inoue \& Lee 2011). According to the neoclassical economic view, if managers are paid based on short-term performance, they will act and make decisions in order to increase short-term profitability because, in doing so, they can maximise their compensation. This way of acting allows the enterprise to increase firm profitability but, on the other hand, short-term decisions conflict with long-term profitability and efficiency; for example, investments that require long-term returns might not be undertaken (Falck \& Heblich 2007). Long-term profitability can be calculated as financial performance with marketbased measures. The market-based measures, such as Tobin's Q, represent the market evaluation of future profitability; in other words, these measures reveal how investors evaluate the capacity of the firm to invest in resources that help to create future profits (Inoue \& Lee 2011; Park \& Lee 2009). To avoid the problems caused by focusing on shortterm performance alone, and in order to motivate managers to act from a long-term perspective as well, the firm should implement incentives consisting of a form of remuneration that managers will obtain if a long-term purpose is achieved (Falck \& Heblich 2007).

Figure 1 shows the proposed theoretical framework in terms of the two stakeholder orientation models, namely, the strategic stakeholder management model (Models 1 and 2) and the intrinsic stakeholder commitment model (Model 3). The strategic stakeholder management model assumes that firm strategy aims to achieve financial success and, although stakeholder interests are considered to be part of the strategy, they do not necessarily drive it. At the same time, stakeholders are part of the firm's environment and they need to be managed, as their actions could affect the firm. So, from this perspective, stakeholder management, represented as CSR activities, are taken into consideration only if they are seen to have strategic value to the firm and its shareholders, for example, better $\mathrm{CFP}$, and if the relation is merely instrumental. 
Since there is no theoretical means to argue whether or not stakeholder management through CSR activities directly affects firm strategy, the proposed theoretical framework includes the two alternative perspectives (see Figure 1). Model 1 (direct effects model), assumes that CSR activities have a direct effect on CFP, independent of firm strategy. Model 2 (moderation model), on the other hand, assumes that CSR activities have an impact on firm strategy by moderating the relationship between firm strategy and CFP.

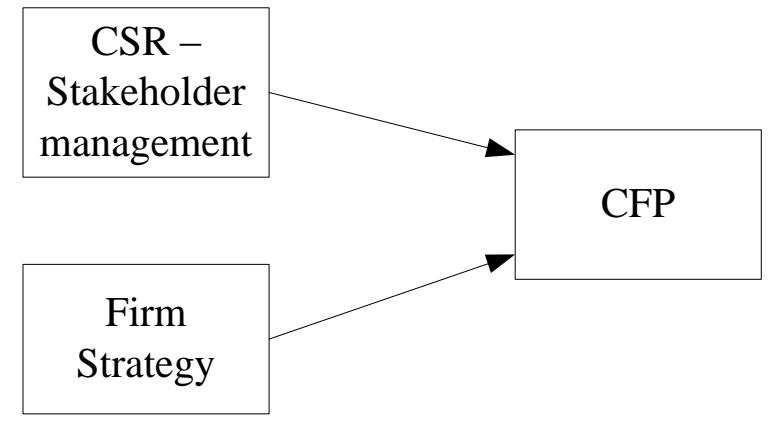

Model 1: Strategic Stakeholder Management: The Direct Effects Model

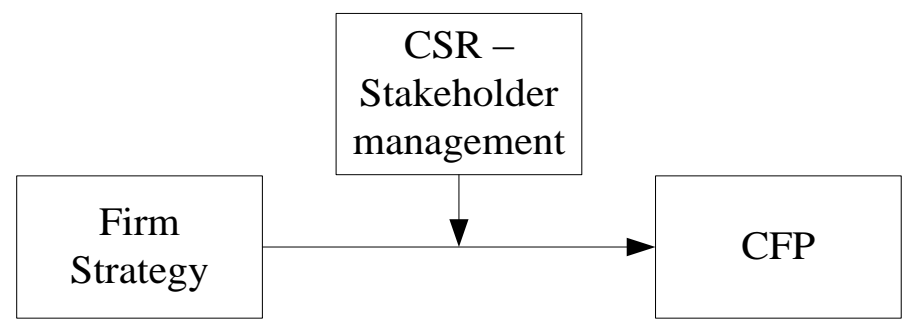

Model 2: Strategic Stakeholder Management: The Moderation Model

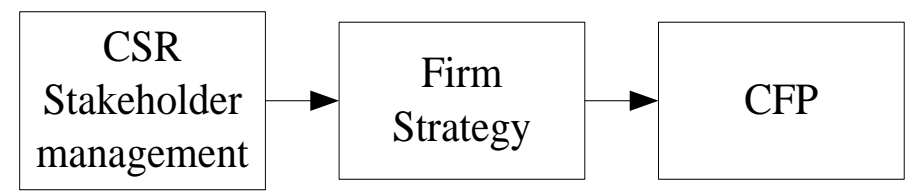

Model 3: The Intrinsic Stakeholder Commitment Model

Figure 1. Research Models Based on Berman et al. (1999)

On the basis of the stakeholder management model, we propose two hypotheses to test the two different perspectives. Hypothesis 1 examines the direct effect of CSR activities on CFP independently of firm strategy, whereas Hypothesis 2 examines the moderated effects of CSR activities on the relationship between firm strategy and CFP.

\section{Hypothesis 1: Direct Effect}

For tourism-related industries, both the firm's strategy variables and stakeholder management, represented as CSR variables, have a direct and separate effect on CFP (short term and long term). 


\section{Hypothesis 2: Moderated Effect}

For tourism-related industries, the firm's strategy variables have a direct effect on CFP (short term and long term), which is moderated by the stakeholder management, represented as CSR variables.

The second perspective proposed by Berman et al. (1999), the intrinsic stakeholder commitment model (Model 3) shown in Figure 1, assumes that firms establish certain moral principles and take appropriate CSR actions as a result of established normative commitments towards their stakeholders. These commitments drive firm strategy rather than simply aiming to maximise profits for the benefit of shareholders. The origins of such a perspective lie with business ethics literature and assume that stakeholder interests and the corresponding CSR activities are the foundation of the firm's strategy. They are seen to have intrinsic value for the firm and form a moral foundation upon which the firm's strategy is established. In other words, the firm's strategy mediates the relationship between stakeholder management, expressed as CSR activities, and CFP (Model 3 in Figure 1). On the basis of the intrinsic stakeholder commitment model, we propose an additional hypothesis that examines the mediating effect of firm strategy.

\section{Hypothesis 3: Intermediated Effect}

For tourism-related industries, managerial commitment to stakeholder management, expressed as CSR variables, drives the firm's strategy, which in turn affects CFP (short term and long term).

The proposed theoretical framework addresses the different perspectives in which the firm handles stakeholder relationships through CSR activities relating to employee relations, product/customer issues, community relations, diversity and environmental performance, and the way that these affect its financial performance. In addition, the framework examines the impact of CSR on both the short-term profitability of the firm and the market evaluation for future profitability. Our aim is to empirically investigate which one of the models best fits the data for the tourism-related industries and to draw the appropriate conclusions based on the results. Finally, in all of the models it was assumed that the operating environment was a control variable (Berman et al. 1999) in order to help us to isolate their impact on CFP. The operating environment is measured at industry level and captures structural conditions for environmental uncertainty from the organisational theory literature (Berman et al. 1999). 


\section{Methodology}

\subsection{Data}

The data was collected using two sources: MSCI ESG and COMPUSTAT. The MSCI ESG data set contains ratings of the performance of the social and environmental activity of firms and COMPUSTAT includes the variables used as dependent variables (ROA and Tobin's Q) and the operating environment variables used as controls. In total, our sample considered 10 years of data for the period 2005-14. Table 2 shows the number of firms by industry that were considered in each year, the total number of observations across all years, the average number of cases (total for each industry/year) and the contribution of each sector (total for each industry/total of all industries).

\begin{tabular}{|l|c|c|c|c|c|c|c|c|c|c|c|c|c|}
\hline & $\mathbf{2 0 0 5}$ & $\mathbf{2 0 0 6}$ & $\mathbf{2 0 0 7}$ & $\mathbf{2 0 0 8}$ & $\mathbf{2 0 0 9}$ & $\mathbf{2 0 1 0}$ & $\mathbf{2 0 1 1}$ & $\mathbf{2 0 1 2}$ & $\mathbf{2 0 1 3}$ & $\mathbf{2 0 1 4}$ & Total & Average & Contrib. \\
\hline Airline & 8 & 8 & 12 & 11 & 11 & 11 & 9 & 10 & 10 & 10 & 100 & 10 & $14.6 \%$ \\
\hline Casino & 14 & 14 & 14 & 14 & 16 & 16 & 14 & 15 & 12 & 13 & 142 & 14.2 & $20.8 \%$ \\
\hline Hotel & 10 & 13 & 12 & 12 & 11 & 12 & 13 & 12 & 11 & 14 & 120 & 12 & $17.6 \%$ \\
\hline Restaurant & 29 & 32 & 31 & 30 & 35 & 34 & 32 & 33 & 32 & 33 & 321 & 32.1 & $47 \%$ \\
\hline Total & 61 & 67 & 70 & 67 & 73 & 73 & 68 & 70 & 65 & 70 & 683 & 68.3 & $100 \%$ \\
\hline
\end{tabular}

Table 2: Number of Initial Observations by Industry and by Year

The two data sets, MSCI ESG and COMPUSTAT, were merged following a two-step process. First, the Committee on Uniform Security Identification Procedures (CUSIP) number was added for each firm in the MSCI ESG data set manually, and then the two data sets were merged based on the values of two key fields: CUSIP and Year. Merging of the two data sets using the ticker symbol was not feasible since the ticker symbol changes over time and, more importantly, there were variations and missing ticker data in the MSCI ESG data set. The final data set contains a total of 683 observations across all four industries.

\subsection{Dependent Variables}

In order to evaluate CFP, two different measures were used: ROA and Tobin's Q. The variable ROA, an accounting variable, is often used to measure the relationship between CSR and CFP (Inoue \& Lee 2011; Berman et al. 1999; Kang et al. 2010). However, ROA should be used with caution because this variable measures short-term performance and, as 
such, is very sensitive to management's choice of asset valuation principles. ROA has been calculated as:

$$
\mathrm{ROA}=(\text { oibdp }-\mathrm{dp}-\mathrm{xint}) / \text { at } \quad \text { Eq. } 1
$$

where oibdp is the operating income before depreciation, $d p$ is the depreciation and amortisation, xint is the total interest and related expense and at is the total assets.

Future profitability was measured by Tobin's Q, a widely applied measure within the corporate governance literature serving as a proxy for a firm's ability to generate shareholder wealth (Weston \& Chung 1990). It has been used extensively in previous tourism-related studies (Inoue \& Lee, 2011; Kang et al., 2010; Lee \& Park, 2009b). Tobin's Q has been calculated as:

$$
\text { Tobin's } \mathrm{Q}=(\mathrm{mkvalt}+\mathrm{pstkl}+\mathrm{dlc}) / \text { at } \quad \text { Eq. } 2
$$

where mkvalt is the market value, calculated as shares outstanding * price of the stock, $p s t k l$ is the value of preferred stock, $d l c$ is the current debt and at is the total assets.

\subsection{Independent Variables}

\subsubsection{CSR - Stakeholder Management}

As a proxy for stakeholder management, we used variables from five categories of ratings of the performance of social and environmental activity of firms from the MSCI ESG data set. These are: employee relations (EMP), product (PRO), community (COM), diversity (DIV) and environmental performance (ENV) (MSCI 2015b). These five different major stakeholder management activity areas represent the level of CSR activities for primary stakeholders (Clarkson 1995) and have been used extensively in previous related empirical studies (Park \& Lee, 2009; Inoue \& Lee, 2011; Kang et al., 2010; Lee, Singal et al., 2013; Lee, Seo et al., 2013; Singal, 2014; Kim \& Kim, 2014; Youn et al., 2015). Each of the five categories (themes) contains measures of key issues relating to the social and environmental performance of firms. Key issues were classified according to whether they represented strengths (str) or concerns (con) and were assigned a binary score: 1 if the firm met the assessment criteria and 0 if not. If a firm had not been researched then the value was NR (not researched). Table 3 shows the selected variables (key issues) under each theme. The variables shown in Table 3 were identified on the basis of MSCI ESG variables selected by previous studies and their relevance to our study (Inoue \& Lee 2011), and also 
based on the fact that these variables were measured during the entire time period under examination (2005-2014) for all the firms.

\begin{tabular}{|c|c|}
\hline MSCI ESG Themes & Key Issues (Variables) \\
\hline \multirow{7}{*}{$\begin{array}{c}\text { Social Performance: } \\
\text { Employee Relations } \\
\text { (EMP) }\end{array}$} & Union Relations (EMP-str-A) \\
\hline & Cash Profit Sharing (EMP-str-C) \\
\hline & Employee Involvement (EMP-str-D) \\
\hline & Employee Health \& Safety (EMP-str-G) \\
\hline & Union Relation Concerns (EMP-con-A) \\
\hline & Health \& Safety (EMP-con-B) \\
\hline & Labour Rights \& Supply Chain - Other Concerns (EMP-con-X) \\
\hline \multirow{6}{*}{$\begin{array}{l}\text { Social Performance: } \\
\text { Product (PRO) }\end{array}$} & Product Safety and Quality (PRO-str-A) \\
\hline & Social Opportunities - Access to Health Care (PRO-str-C) \\
\hline & Product Quality and Safety (PRO-con-A) \\
\hline & Marketing \& Advertising (PRO-con-D) \\
\hline & Anti-competitive Practices (PRO-con-E) \\
\hline & Other Concerns (PRO-con-X) \\
\hline \multirow{2}{*}{$\begin{array}{l}\text { Social Performance: } \\
\text { Community (COM) }\end{array}$} & Community Engagement (COM-str-H) \\
\hline & Community Impact (COM-con-B) \\
\hline \multirow{8}{*}{$\begin{array}{c}\text { Environmental } \\
\text { Performance (ENV) }\end{array}$} & Environmental Opportunities - Clean Tech (ENV-str-A) \\
\hline & Waste Management - Toxic Emissions and Waste (ENV-str-B) \\
\hline & Waste Management - Packaging Materials \& Waste (ENV-str-C) \\
\hline & Climate Change - Carbon Emissions (ENV-str-D) \\
\hline & Environmental Management Systems (ENV-str-G) \\
\hline & Regulatory Compliance (ENV-con-B) \\
\hline & Toxic Emissions and Waste (ENV-con-D) \\
\hline & Energy and Climate Change (ENV-con-F) \\
\hline \multirow{2}{*}{$\begin{array}{l}\text { Social Performance: } \\
\text { Diversity (DIV) }\end{array}$} & Board of Directors - Gender (DIV-str-C) \\
\hline & Workforce Diversity (DIV-con-A) \\
\hline
\end{tabular}

Table 3. MSCI ESG Variables 


\subsubsection{Firm Strategy}

Similarly to Berman et al. (1999), and to isolate the effects of strategic decision-making in relation to CFP, we used Hambrick's (1983) measurement of the strategy constructs, which uses measures on cost efficiency, asset parsimony, differentiation and scale/scope. The four dimensions are: selling intensity (SI), the differentiation measure that captures a firm's willingness to spend on marketing and selling-related activities in an effort to differentiate itself from its rivals (see Eq. 3); capital expenditure (CE), the net capital expenditure made by the firm in a given year divided by its sales for that year (see Eq. 4); cost efficiency (EF), the ratio of the cost of services and goods sold to total sales (a smaller value indicates better operating efficiency (see Eq. 5)); and capital intensity (CI), the total firm assets for a given year divided by the number of employees for that year (see Eq. 6).

$$
\begin{array}{ll}
\mathrm{SI}=\mathrm{xsga} / \mathrm{at} & \text { Eq. } 3 \\
\mathrm{CE}=\text { capx/sale } & \text { Eq. } 4 \\
\mathrm{EF}=\text { cogs/sale } & \text { Eq. } 5 \\
\mathrm{CI}=\text { at/emp } & \text { Eq. } 6
\end{array}
$$

where $x$ sga is selling, general and administrative expenses, at is the total assets, capx is the net capital expenditure, sale are the sales, $\operatorname{cog} s$ is the cost of services and goods sold and emp is the number of employees.

\subsection{Control Variables}

When performance is the dependent variable, the operating environment plays a significant role (Jauch \& Kraft 1986). Using operating environment variables as control variables helps to isolate their effects on CFP (Berman et al. 1999). Furthermore, the operating environment captures the structural conditions for environmental uncertainty and, thus, it is measured at industry level (Berman et al. 1999).

For the purposes of this study, the operating environment was measured using three variables: munificence, dynamism and power (Berman et al. 1999). Munificence (MU) for year 2005 is the coefficient (slope) of the regression of industry-level sales for the 19992004 period. It was updated using a rolling window for every year in the data set until 2014. Dynamism (DY) is the standard error of the regression used to calculate munificence, divided by the mean of industry sales for the corresponding period. Finally, power (PO) was measured as the four-firm concentration level, calculated as the percentage 
of sales generated by the top four firms relative to the total industry sales, also following the same rolling window basis. Each operating environment variable was calculated separately for each of the four industries in the study.

\subsection{Models}

A multiple regression panel analysis was developed in order to test the effects of the stakeholders' management through CSR activities on both short-term (ROA) and long-term (Tobin's Q) profitability, controlling by strategy and operating environment variables:

$Y_{i, t}=\alpha_{i}+\beta_{1} O E_{i, t}+\beta_{2} S_{i, t}+\beta_{3} S T R_{i, t}+\varepsilon_{i, t}$ Eq. 7

where the subscript $i$ indexes the firm, $t$ describes the time period $(\mathrm{t}=1[2005], \ldots, \mathrm{t}=10$ [2015]), $Y_{t}$ defines the dependent performance variable for year $t$, either ROA or Tobin's $\mathrm{Q}, \alpha_{i}$ is the fixed firm-specific effect, $\mathrm{OE}_{\mathrm{i}, \mathrm{t}}$ represents the set of operating environment variables, $\mathrm{S}_{\mathrm{i}, \mathrm{t}}$ is the set of strategy variables, and $\mathrm{STR}_{\mathrm{i}, \mathrm{t}}$ is the set of stakeholder relationship (CSR) variables.

To test the moderating role of firm strategy on the relationship between CSR and firm performance, we also analysed the following specification:

$Y_{i, t}=\alpha_{i}+\beta_{1} O E_{i, t}+\beta_{2} S_{i, t}+\beta_{3} S T R_{i, t}+\beta_{4} S_{i, t} \cdot S T R_{i, t}+\varepsilon_{i, t}$ Eq. 8

In particular, $\alpha_{i}, \beta_{1}, \beta_{2}, \beta_{3}$ and $\beta_{4}$ are the coefficients of the model for the respective explanatory variables and $\varepsilon_{\mathrm{i}, \mathrm{t}}$ is the error term of the model.

Both Equations 7 and 8 were used to estimate unbalanced panel regression models pooling data for all four industries. Specifically, Equation 7 was used to test Model 1 and Equation 8 was used to test Model 2, as shown in Figure 1. Model 3 is a restricted model including only the control and CSR variables. Separate panel regressions were also tested for each industry, including intermediated effects, as shown in Figure 1. 


\section{Results}

\subsection{Descriptive Statistics}

Table 4 illustrates a summary of the descriptive statistics of the variables studied (strategy, CSR, CFP and operating environment variables) across all the tourism-related industries. From Table 4 we can see that the minimum values of most CSR variables are negative and the mean for EMP and PRO is also negative.

\begin{tabular}{|c|c|c|c|c|c|}
\hline Variable & Obs & Mean & Std Dev. & Min. & Max. \\
\hline \multicolumn{6}{|l|}{ Financial performance } \\
\hline ROA & 683 & 0.082 & 0.098 & -0.256 & 0.542 \\
\hline Tobin's Q & 683 & 1.440 & 1.426 & 0.004 & 10.274 \\
\hline \multicolumn{6}{|l|}{ Operating environment } \\
\hline Dynamism (DY) & 683 & 0.037 & 0.018 & 0.016 & 0.076 \\
\hline Munificence (MU) & 683 & 1.526 & 0.734 & 0.442 & 2.659 \\
\hline Power (PO) & 683 & 0.008 & 0.010 & 0.002 & 0.043 \\
\hline \multicolumn{6}{|l|}{ Strategy } \\
\hline Selling intensity (SI) & 683 & 0.15483 & 0.122504 & 0 & 0.85022 \\
\hline Capital expenditure (CE) & 683 & 10.678 & 13.141 & 0.276 & 128.575 \\
\hline Cost efficiency (EF) & 683 & 0.674 & 0.175 & 0.018 & 0.939 \\
\hline Capital intensity (CI) & 683 & 231.794 & 352.599 & 15.540 & 4443.230 \\
\hline \multicolumn{6}{|l|}{ Stakeholders CSR } \\
\hline Employees (EMP) & 683 & -0.183 & 0.692 & -3.000 & 2.000 \\
\hline Product safety/quality (PRO) & 683 & -0.111 & 0.493 & -3.000 & 1.000 \\
\hline Diversity (DIV) & 683 & 0.010 & 0.365 & -1.000 & 1.000 \\
\hline Environment (ENV) & 683 & 0.078 & 0.336 & -1.000 & 2.000 \\
\hline Community (COM) & 683 & 0.006 & 0.076 & 0.000 & 1.000 \\
\hline
\end{tabular}

Table 4: Summary of Descriptive Statistics

Table 5 illustrates a descriptive summary of the variables studied for two of the tourismrelated industries, namely, airlines and casinos. The total number of observations across the 10-year period (2005-2014) for airlines is 100, and for casinos it is 142 .

Table 6 illustrates a descriptive summary of the variables studied for the other two tourismrelated industries, namely, hotels and restaurants. The total number of observations across the 10-year period (2005-2014) for hotels is 120, and for restaurants it is 321 . 
In relation to the specific sector and industry characteristics, the descriptive statistics provide an overview that can be used for comparison purposes between sectors/industries. For example, in comparison with the manufacturing sector, as reported by Berman et al. (1999), a service sector such as tourism shows a much higher capital intensity (231.7 versus 7.9), which might be explained by the fact that the tourism industries have large investments in fixed assets, such as airplanes and buildings (hotels, restaurants, casinos).

\begin{tabular}{|c|c|c|c|c|c|c|c|c|c|c|}
\hline \multirow[b]{2}{*}{ Variable } & \multicolumn{5}{|c|}{ Panel I: Airline Industry } & \multicolumn{5}{|c|}{ Panel II: Casino Industry } \\
\hline & Obs & Mean & Std Dev. & Min. & Max. & Obs & Mean & Std Dev. & Min. & Max. \\
\hline \multicolumn{11}{|l|}{$\begin{array}{l}\text { Financial } \\
\text { performance }\end{array}$} \\
\hline ROA & 100 & 0.042 & 0.078 & -0.221 & 0.260 & 142 & 0.045 & 0.077 & -0.140 & 0.276 \\
\hline Tobin's Q & 100 & 0.612 & 0.618 & 0.086 & 3.446 & 142 & 1.039 & 0.915 & 0.004 & 4.452 \\
\hline \multicolumn{11}{|l|}{$\begin{array}{l}\text { Operating } \\
\text { environment }\end{array}$} \\
\hline $\begin{array}{r}\text { Dynamism } \\
\text { (DY) }\end{array}$ & 100 & 0.029 & 0.012 & 0.020 & 0.066 & 142 & 0.044 & 0.019 & 0.021 & 0.076 \\
\hline $\begin{array}{r}\text { Munificence } \\
\text { (MU) }\end{array}$ & 100 & 0.676 & 0.167 & 0.442 & 0.988 & 142 & 0.972 & 0.143 & 0.686 & 1.169 \\
\hline $\begin{array}{r}\text { Power } \\
(\mathrm{PO})\end{array}$ & 100 & 0.031 & 0.010 & 0.010 & 0.043 & 142 & 0.004 & 0.001 & 0.002 & 0.006 \\
\hline \multicolumn{11}{|l|}{ Strategy } \\
\hline $\begin{array}{r}\text { Selling intensity } \\
\text { (SI) }\end{array}$ & 100 & 0.105 & 0.047 & 0.000 & 0.216 & 142 & 0.224 & 0.111 & 0.022 & 0.599 \\
\hline $\begin{array}{r}\text { Capital expenditure } \\
\text { (CE) }\end{array}$ & 100 & 10.570 & 10.060 & 0.714 & 66.068 & 142 & 17.767 & 21.002 & 0.276 & 128.575 \\
\hline $\begin{array}{r}\text { Cost efficiency } \\
\text { (EF) }\end{array}$ & 100 & 0.768 & 0.073 & 0.592 & 0.939 & 142 & 0.550 & 0.162 & 0.018 & 0.875 \\
\hline $\begin{array}{r}\text { Capital intensity } \\
(\mathrm{CI})\end{array}$ & 100 & 377.259 & 151.714 & 32.226 & 808.982 & 142 & 369.620 & 382.387 & 63.605 & 4443.23 \\
\hline \multicolumn{11}{|l|}{$\begin{array}{l}\text { Stakeholders } \\
\text { CSR }\end{array}$} \\
\hline $\begin{array}{r}\text { Employees } \\
\text { (EMP) }\end{array}$ & 100 & 0.210 & 0.957 & -2.000 & 2.000 & 142 & -0.092 & 0.411 & -2.000 & 1.000 \\
\hline $\begin{array}{r}\text { Product safety/qual. } \\
\text { (PRO) }\end{array}$ & 100 & -0.120 & 0.556 & -2.000 & 1.000 & 142 & -0.239 & 0.532 & -3.000 & 1.000 \\
\hline $\begin{array}{r}\text { Diversity } \\
\text { (DIV) }\end{array}$ & 100 & 0.090 & 0.351 & -1.000 & 1.000 & 142 & 0.014 & 0.118 & 0.000 & 1.000 \\
\hline $\begin{array}{r}\text { Environment } \\
(\mathrm{ENV})\end{array}$ & 100 & 0.140 & 0.349 & 0.000 & 1.000 & 142 & 0.042 & 0.202 & 0.000 & 1.000 \\
\hline $\begin{array}{r}\text { Community } \\
(\mathrm{COM})\end{array}$ & 100 & 0.000 & 0.000 & 0.000 & 0.000 & 142 & 0.021 & 0.144 & 0.000 & 1.000 \\
\hline
\end{tabular}

Table 5: Summary of Descriptive Statistics for Airlines and Casinos

Moreover, for the wider sector characteristics, as captured by the operating environment, the tourism sector shows a much higher MU than manufacturing (1.5 versus 0.01 ), which can be explained by the fact that the tourism sector, especially the restaurant industry (see 
Table 6), is performing much better in terms of increasing sales over the years. Finally, in relation to the CSR variables, EMP and ENV have opposite signs in the two sectors, which might be explained by the fact that the manufacturing sector places more emphasis on employee policies (positive) and faces more pressure in relation to their environmental performance (negative).

\begin{tabular}{|c|c|c|c|c|c|c|c|c|c|c|}
\hline \multirow[b]{2}{*}{ Variable } & \multicolumn{5}{|c|}{ Panel III: Hotel Industry } & \multicolumn{5}{|c|}{ Panel IV: Restaurant Industry } \\
\hline & Obs & Mean & Std Dev. & Min. & Max. & Obs & Mean & Std Dev. & Min. & Max. \\
\hline \multicolumn{11}{|l|}{$\begin{array}{l}\text { Financial } \\
\text { performance }\end{array}$} \\
\hline ROA & 120 & 0.089 & 0.122 & -0.076 & 0.542 & 321 & 0.108 & 0.091 & -0.256 & 0.428 \\
\hline Tobin's Q & 120 & 1.444 & 1.721 & 0.112 & 10.274 & 321 & 1.874 & 1.507 & 0.095 & 8.449 \\
\hline \multicolumn{11}{|l|}{$\begin{array}{l}\text { Operating } \\
\text { environment }\end{array}$} \\
\hline $\begin{array}{r}\text { Dynamism } \\
\text { (DY) }\end{array}$ & 120 & 0.038 & 0.010 & 0.022 & 0.059 & 321 & 0.037 & 0.021 & 0.016 & 0.075 \\
\hline $\begin{array}{r}\text { Munificence } \\
\text { (MU) }\end{array}$ & 120 & 0.910 & 0.125 & 0.716 & 1.140 & 321 & 2.267 & 0.263 & 1.804 & 2.659 \\
\hline $\begin{array}{r}\text { Power } \\
(\mathrm{PO})\end{array}$ & 120 & 0.007 & 0.001 & 0.006 & 0.010 & 321 & 0.004 & 0.001 & 0.002 & 0.005 \\
\hline \multicolumn{11}{|l|}{ Strategy } \\
\hline $\begin{array}{r}\text { Selling intensity } \\
\text { (SI) }\end{array}$ & 120 & 0.222 & 0.180 & 0.000 & 0.850 & 321 & 0.115 & 0.088 & 0.043 & 0.621 \\
\hline $\begin{array}{r}\text { Capital expenditure } \\
\text { (CE) }\end{array}$ & 120 & 11.307 & 15.370 & 0.864 & 91.632 & 321 & 7.341 & 4.574 & 0.868 & 24.407 \\
\hline $\begin{array}{r}\text { Cost efficiency } \\
\text { (EF) }\end{array}$ & 120 & 0.551 & 0.217 & 0.024 & 0.926 & 321 & 0.745 & 0.120 & 0.211 & 0.898 \\
\hline $\begin{array}{r}\text { Capital intensity } \\
(\mathrm{CI})\end{array}$ & 120 & 279.554 & 266.971 & 47.999 & 2137.052 & 321 & 107.654 & 368.184 & 15.540 & 2914.414 \\
\hline \multicolumn{11}{|l|}{$\begin{array}{l}\text { Stakeholders } \\
\text { CSR }\end{array}$} \\
\hline $\begin{array}{r}\text { Employees } \\
\text { (EMP) }\end{array}$ & 120 & -0.233 & 0.658 & -2.000 & 1.000 & 321 & -0.327 & 0.653 & -3.000 & 1.000 \\
\hline $\begin{array}{r}\text { Product safety/qual. } \\
\text { (PRO) }\end{array}$ & 120 & -0.058 & 0.523 & -2.000 & 1.000 & 321 & -0.072 & 0.431 & -2.000 & 1.000 \\
\hline $\begin{array}{r}\text { Diversity } \\
\text { (DIV) }\end{array}$ & 120 & 0.067 & 0.250 & 0.000 & 1.000 & 321 & -0.037 & 0.459 & -1.000 & 1.000 \\
\hline $\begin{array}{r}\text { Environment } \\
(\text { ENV) }\end{array}$ & 120 & 0.117 & 0.505 & -1.000 & 2.000 & 321 & 0.059 & 0.295 & -1.000 & 2.000 \\
\hline $\begin{array}{r}\text { Community } \\
(\mathrm{COM})\end{array}$ & 120 & 0.000 & 0.000 & 0.000 & 0.000 & 321 & 0.003 & 0.056 & 0.000 & 1.000 \\
\hline
\end{tabular}

Table 6: Summary of Descriptive Statistics for Hotels and Restaurants

Table 7 shows the results for the correlation analysis for airlines, casinos, hotels and restaurants. Overall, EMP had a negative significant correlation with both short- and longterm CFP (ROA and Tobin's Q); however, the correlation is relatively low in absolute 
terms (less than 0.12). The remaining CSR indicators presented no significant correlations with the CFP indicators.

In relation to the operating environment variables, ROA had a significant negative correlation with DY and PO, and a significant and positive correlation with MU; however, in terms of the absolute size of the correlations, these are also on the low range (less than 0.21). Similarly, Tobin's $Q$ had a significant negative correlation with $P O$ and a positive and significant correlation with MU, also in the low range when considering the size of the correlation (less than 0.24 in absolute terms). In short, all operating environment variables were correlated significantly with short-term performance (ROA), and all operating environment variables, with the exception of DY, were significantly correlated with Tobin's Q, and the size of these correlations in absolute terms was in the low range.

\begin{tabular}{|c|c|c|c|c|c|c|c|c|c|c|c|c|c|c|}
\hline & ROA & Tobin's Q & DY & MU & $\mathrm{PO}$ & SI & $\mathrm{CE}$ & $\mathrm{EF}$ & CI & EMP & PRO & DIV & ENV & $\mathrm{COM}$ \\
\hline ROA & 1 & & & & & & & & & & & & & \\
\hline Tobin's Q & $0.7820 *$ & 1 & & & & & & & & & & & & \\
\hline $\begin{array}{l}\text { Dynamism } \\
\text { (DY) }\end{array}$ & $-0.0959 *$ & -0.0353 & 1 & & & & & & & & & & & \\
\hline $\begin{array}{l}\text { Munificence } \\
\text { (MU) }\end{array}$ & $0.2090 *$ & $0.2416 *$ & $0.1872 *$ & 1 & & & & & & & & & & \\
\hline $\begin{array}{l}\text { Power } \\
\text { (PO) }\end{array}$ & $-0.1275^{*}$ & $-0.2119 *$ & $-0.2595 *$ & $-0.5468 *$ & 1 & & & & & & & & & \\
\hline $\begin{array}{l}\text { Selling } \\
\text { intensity } \\
\text { (SI) }\end{array}$ & $-0.1203 *$ & $-0.1190^{*}$ & 0.0547 & $-0.2693 *$ & $-0.1185^{*}$ & 1 & & & & & & & & \\
\hline $\begin{array}{c}\text { Capital } \\
\text { expenditure } \\
\text { (CE) }\end{array}$ & $-0.2020 *$ & -0.0541 & $0.1652 *$ & $-0.1906^{*}$ & -0.0129 & $0.1312 *$ & 1 & & & & & & & \\
\hline $\begin{array}{c}\text { Cost } \\
\text { efficiency } \\
\text { (EF) }\end{array}$ & $-0.1133 *$ & -0.0279 & -0.0153 & $0.3439 *$ & $0.1443^{*}$ & $-0.8634 *$ & $-0.1744 *$ & 1 & & & & & & \\
\hline $\begin{array}{c}\text { Capital } \\
\text { intensity } \\
\text { (CI) }\end{array}$ & $-0.0760 *$ & $-0.1352 *$ & -0.0537 & $-0.3440 *$ & 0.1930* & $0.2148 *$ & $0.1394 *$ & $-0.3903 *$ & 1 & & & & & \\
\hline $\begin{array}{l}\text { Employees } \\
\text { (EMP) }\end{array}$ & $-0.1064 *$ & $-0.0769 *$ & $-0.1365^{*}$ & $-0.2715^{*}$ & 0.2370* & $0.0856^{*}$ & 0.0077 & -0.0576 & $0.1410^{*}$ & 1 & & & & \\
\hline $\begin{array}{c}\text { Product } \\
\text { safety/quality } \\
\text { (PRO) }\end{array}$ & -0.005 & 0.0277 & 0.0249 & 0.0626 & -0.0205 & -0.0265 & -0.032 & $0.0755^{*}$ & 0.015 & $0.2027 *$ & 1 & & & \\
\hline $\begin{array}{l}\text { Diversity } \\
\text { (DIV) }\end{array}$ & -0.0363 & -0.0293 & 0.0178 & $-0.0921 *$ & 0.0622 & -0.044 & 0.0439 & 0.0115 & $0.1354 *$ & $-0.0855^{*}$ & -0.067 & 1 & & \\
\hline $\begin{array}{l}\text { Environment } \\
\text { (ENV) }\end{array}$ & 0.0117 & 0.0403 & -0.0556 & $-0.0998 *$ & $0.1169^{*}$ & $-0.1041 *$ & $-0.0884 *$ & $0.0935^{*}$ & -0.0117 & $0.0802 *$ & $0.1232 *$ & 0.0174 & 1 & \\
\hline $\begin{array}{l}\text { Community } \\
\text { (COM) }\end{array}$ & -0.012 & 0.0095 & -0.0057 & -0.0149 & -0.0315 & -0.0054 & 0.0087 & -0.0338 & 0.0267 & $-0.1185^{*}$ & $-0.2945^{*}$ & 0.0504 & 0.0394 & 1 \\
\hline
\end{tabular}

Table 7: Correlations

In relation to the strategy variables, ROA was correlated negatively with all of them, and Tobin's Q with all of them apart from $\mathrm{CE}$ and EF, which also showed effect sizes that were 
in the low range (absolute correlation of less than 0.20). Overall, the correlation analysis presents preliminary evidence that points towards the existence of a significant effect of CSR, strategy and operating variables on financial performance, but these effects, when analysed in a pairwise way, were relatively small.

\subsection{Panel Regression Results}

Tables 8 and 9 provide the results of the panel regression analysis. Table 8 reports the results for all the models to test Hypotheses 1, 2 and 3 across all four tourism-related industries. For all the models, we present alternative specifications for both ROA and Tobin's Q. For each specification, the first column shows the unstandardised regression coefficients, and the second column shows the robust standard errors in parentheses. Furthermore, for all the models, operating environment variables are also included as control variables.

Specifically, in Table 8, Model 1 is examined in two alternative specifications. Model 1a is a restricted model and only considers the direct effects of firm strategy on CFP (Berman et al. 1999). Model 1b, the full model, considers the direct effects of both firm strategy and CSR on CFP, controlling by operating environment. Models $1 \mathrm{a}$ and $1 \mathrm{~b}$ are used to test Hypothesis 1, which states that CSR and firm strategy each have direct and separate impacts on CFP. Of the five stakeholder relationships, two are significant for ROA: COM and PRO; and one for Tobin's Q: EMP. Moreover, it is possible to appreciate that, in general, operating environment variables and strategy variables have similar effect sizes, which are also much larger than the effect size of the CSR variables. However, it is important to notice that, although small, the direct effect of the CSR variables on financial performance variables is still statistically significant, at least at the 5 per cent significance threshold.

Model 2, in Table 8, considers the moderating effects of CSR on the relationship between firm strategy and CFP and is used to test Hypothesis 2. Model 2 includes all the variables in the full model (Model 1b) and all the interaction terms between firm strategy and CSR variables. For ROA, none of the five CSR variables have a significant direct effect but this changes when considering the interactions with the strategy variables. In this case, PRO and ENV have a significant and positive interaction with CI, DIV has a weak and positive interaction with CI and, finally, PRO has a weak and negative interaction with CE. For Tobin's Q, we find a positive and significant direct effect of COM, and a significant 
positive effect on the interaction of PRO and ENV with CI. We also find a significant negative effect on the interaction of EMP with CE, and COM with SI. Two weak interactions are also observed: a negative interaction between PRO and SI, and a positive interaction between DIV and CI. Again, when considering effect sizes, the operating environment and strategy variables present the larger effects in absolute terms; however, it is also possible to appreciate large effects of the CSR variables COM and PRO when interacted with SI. Other CSR x CI interaction effects are significant but much smaller.

Model 3, in Table 8, corresponds to the intrinsic stakeholders' commitment model, and examines the relationship between CSR and CFP, mediated by the firm's strategy. It is used to test Hypothesis 3. Model 3 is a restricted model, including only the control and CSR variables. Firm strategy variables are included in the full model, Model 1b. If strategy mediated the CSR-CFP relationship, any statistically significant CSR variables in Model 3 should no longer be significant in Model 1b. The results lend little support to the intrinsic stakeholder commitment model, since variables significant in Model 3 (EMP for Tobin's Q) are still significant in Model 1b, or variables that are not significant in Model 3 (PRO and COM for ROA) become significant in Model 1b. From the panel regression results for the tourism sector shown in Table 8, we find support for the strategic stakeholder management models, namely, Model 2 (moderated model) and Model 1 (direct effects model). We then examine how Model 2 is applied in each of the four tourism industries under consideration, namely, airlines, casinos, hotels and restaurants. The main reason for this is that the previous literature, as discussed earlier, mostly examines the direct effects model for the various tourism industries and has not been able to provide consistent results; it has only recently identified the need to examine the relationship between CSR and CFP under the moderating effects of either firm-level or industry-level characteristics.

In Table 9 the results of the panel regressions for Model 2 (moderated model) are presented for each of the four tourism-related industries. Again, for each industry two specifications are presented, one for ROA and one for Tobin's Q. For each specification, the first column shows the unstandardised regression coefficients, and the second column shows the robust standard errors in parentheses.

For airlines, as shown in Table 9, for ROA only one of the five CSR variables has a significant negative direct effect, namely DIV $(-0.56 *)$. Considering the interactions, we find one significant positive interaction, $\mathrm{EF} \times \mathrm{DIV}\left(0.47^{*}\right)$, and one weak positive interaction, CI x DIV (0.0008 $\dagger)$. For Tobin's Q, the same CSR variable has a weak 
negative effect, namely, DIV (-3.29†). We also find two significant interactions: a positive interaction between $\mathrm{CE}$ and $\mathrm{ENV}$; and a negative interaction between EF and ENV. Two weak positive interactions are also observed, namely, between EF and DIV and between CI and DIV. In terms of size of the effects in absolute terms, we find larger effects in the Tobin's Q specification, especially for the operating environment variables. For the ROA estimation, the strategy variables SI and EF have the largest effects. With regards to interactions, EF x ENV has the largest effects in the Tobin's Q regression.

For casinos, as shown in Table 9, for ROA one of the five CSR variables has a significant positive direct effect, namely EMP $\left(0.2^{*}\right)$. Considering the interactions, we find four significant negative interactions, namely, between SI and EMP, CE and COM, EF and EMP, and CI and PRO. Furthermore, one weak negative interaction is observed between SI and PRO. For Tobin's Q, we have a significant positive direct effect for EMP (3.86*). Considering the interactions, we find six significant negative interactions, namely, between SI and EMP, SI and PRO, CE and EMP, CE and COM, EF and EMP, and CI and EMP. We also find one significant positive interaction between CI and COM and one weak negative interaction between CI and PRO. In terms of absolute effect sizes, the specification for Tobin's Q exhibits larger coefficients when compared to ROA. In particular, SI, EMP and the interaction between the last two variables shows the larger coefficients, followed closely by the SI x PRO and EF x EMP interactions.

For hotels, as shown in Table 9, for ROA none of the five CSR variables have a significant or weak direct effect on CFP. Considering the interactions, we find one significant negative interaction between SI and EMP and one weak positive interaction between CE and PRO. For Tobin's Q, we have a significant positive direct effect for EMP and a weak positive direct effect for PRO. Considering the interactions, we find three significant negative interactions, namely between SI and EMP, CE and EMP, and EF and EMP. We also find one significant positive interaction between $\mathrm{CE}$ and PRO, and two weak negative interactions between EF and PRO, and between CI and PRO. In terms of the effect sizes, a similar pattern is observed; in other words, coefficients show stronger effects for the Tobin's Q specification, especially for strategy variables SI and EF, for CSR variables EMP and PRO, and for their interactions.

For restaurants, as shown in Table 9, for ROA one of the five CSR variables has a significant positive direct effect, namely ENV $(0.81 * *)$. Considering the interactions, we find six significant negative interactions, namely, between SI and ENV, CE and ENV, EF 
and ENV, CI and EMP, CI and ENV, and CI and COM. Moreover, one significant positive interaction is observed between CE and DIV and one weak negative interaction between EF and PRO. For Tobin's Q, we have a significant positive direct effect for ENV (5.44**). Considering the interactions, we find three significant negative interactions, namely, between EF and ENV, CI and ENV, and CI and COM. We also find one significant positive interaction between EF and EMP and two weak negative interactions between EF and DIV, and CI and EMP. With respect to effect sizes in absolute terms, the Tobin's Q regression exhibits the larger effects, and the largest ones are associated with DY, SI and EF. It is also possible to appreciate smaller effects of ENV, and the EF x EMP and EF $x$ ENV interactions.

\section{Discussion}

Hypothesis 1 is supported for the tourism sector. The hypothesis states that there should be a significant and direct relationship between CSR and CFP for both ROA and Tobin's Q after controlling for firm strategy and operating environment effects. As shown in Model $1 \mathrm{~b}$ in Table 8 , the product and community activities are significantly related to short-term performance (ROA) and the employee relation activities are significantly related to longterm performance (Tobin's Q). It is also possible to observe that the effects of the strategy and CSR variables are generally much larger for the long-term specification, that is, they have a greater impact on long-term financial performance. From the theoretical standpoint, we argue that this empirical result shows how firms aim to achieve financial success taking into consideration different types of stakeholder interest, and how these may impact directly and differently in the short and long terms. For example, managers should consider that the product and community activities may have a direct negative impact on short-term financial performance, whereas the employee relation activities are likely to have a direct positive impact on long-term financial performance. In relation to the environmental performance and diversity activities, managers should be aware that, although these activities do not have a direct impact, they may have an effect through interactions with strategy variables, as examined in Hypothesis 2. 


\begin{tabular}{|c|c|c|c|c|c|c|c|c|c|c|c|c|c|c|c|c|}
\hline \multirow{4}{*}{$\begin{array}{l}\text { Results of Fixed-Effects Panel Regressions } \\
\text { Dependent Variable } \\
\text { Constant }\end{array}$} & \multicolumn{4}{|c|}{ Model 1a } & \multicolumn{4}{|c|}{ Model 1b } & \multicolumn{4}{|c|}{ Model 2} & \multicolumn{4}{|c|}{ Model 3} \\
\hline & \multirow{2}{*}{\multicolumn{2}{|c|}{$\begin{array}{c}(1) \\
\text { ROA }\end{array}$}} & \multirow{2}{*}{\multicolumn{2}{|c|}{$\begin{array}{c}\text { (2) } \\
\text { Tobin's Q }\end{array}$}} & \multirow{2}{*}{\multicolumn{2}{|c|}{$\begin{array}{c}\text { (3) } \\
\text { ROA }\end{array}$}} & \multirow{2}{*}{\multicolumn{2}{|c|}{$\begin{array}{c}(4) \\
\text { Tobin's }\end{array}$}} & \multirow{2}{*}{\multicolumn{2}{|c|}{$\begin{array}{r}(5) \\
\text { ROA } \\
\end{array}$}} & \multirow{2}{*}{\multicolumn{2}{|c|}{$\begin{array}{c}(\boldsymbol{6}) \\
\text { Tobin's Q } \\
\end{array}$}} & \multirow{2}{*}{\multicolumn{2}{|c|}{$\begin{array}{c}(7) \\
\text { ROA }\end{array}$}} & \multirow{2}{*}{\multicolumn{2}{|c|}{$\begin{array}{c}(\mathbf{8}) \\
\text { Tobin's Q }\end{array}$}} \\
\hline & & & & & & & & & & & & & & & & \\
\hline & $0.87^{* *}$ & $(0.11)$ & $8.18^{* * *}$ & $(1.09)$ & 0.87 ** & $(0.11)$ & $7.81^{\text {*** }}$ & $(1.07)$ & $0.93^{\text {*** }}$ & $(0.12)$ & $8.30^{\text {*** }}$ & $(0.99)$ & $0.12 * *$ & $(0.037)$ & $2.38^{* * *}$ & $(0.42)$ \\
\hline \multicolumn{17}{|l|}{ Operating environment } \\
\hline Dynamism (DY) & 0.085 & $(0.14)$ & $6.51^{* *}$ & $(2.30)$ & 0.088 & $(0.14)$ & $6.30^{* * *}$ & $(2.31)$ & 0.12 & $(0.14)$ & $5.99^{* *}$ & $(2.15)$ & -0.21 & $(0.20)$ & $4.70^{\wedge}$ & $(2.60)$ \\
\hline Munificence (MU) & -0.018 & $(0.016)$ & $-0.81 * *$ & $(0.26)$ & -0.018 & $(0.016)$ & $-0.66^{*}$ & $(0.28)$ & -0.022 & $(0.016)$ & $-0.64 *$ & $(0.27)$ & -0.021 & $(0.022)$ & $-0.68 *$ & $(0.29)$ \\
\hline Power (PO) & -0.55 & $(0.69)$ & $-7.67 \dagger$ & $(4.31)$ & -0.64 & $(0.69)$ & $-8.57 \dagger$ & $(4.96)$ & -0.61 & $(0.62)$ & -8.21 & (7.04) & -0.70 & $(1.12)$ & $-9.47^{\wedge}$ & $(5.20)$ \\
\hline \multicolumn{17}{|l|}{ Strategy } \\
\hline Selling intensity (SI) & $-0.98 * *$ & $(0.14)$ & $-8.14 * *$ & $(0.99)$ & $-0.98^{* *}$ & $(0.14)$ & $-8.10 * *$ & $(1.02)$ & $-1.01 * *$ & $(0.15)$ & $-8.30 * *$ & $(0.85)$ & & & & \\
\hline Capital expenditure (CE) & 0.000054 & $(0.00023)$ & $0.0098 * *$ & $(0.0027)$ & 0.000078 & $(0.00023)$ & $0.010^{* *}$ & $(0.0029)$ & 0.000087 & $(0.00024)$ & $0.0096 * *$ & $(0.0017)$ & & & & \\
\hline Cost efficiency (EF) & $-0.90^{* *}$ & $(0.14)$ & $-6.68^{* *}$ & $(1.46)$ & $-0.91 * *$ & $(0.14)$ & $-6.39 * *$ & $(1.47)$ & $-0.96 * *$ & $(0.14)$ & $-6.94 * *$ & $(1.38)$ & & & & \\
\hline Capital intensity (CI) & -0.000015 & $(0.000033)$ & -0.00031 & $(0.00045)$ & -0.000016 & $(0.000031)$ & -0.00035 & $(0.00045)$ & $-0.000053 \dagger$ & $(0.000031)$ & $-0.00073 \dagger$ & $(0.00042)$ & & & & \\
\hline \multicolumn{17}{|l|}{ Stakeholder relationships - CSR } \\
\hline Employees (EMP) & & & & & 0.00067 & $(0.0042)$ & $0.21 *$ & $(0.083)$ & 0.0070 & $(0.089)$ & 0.49 & $(0.87)$ & 0.0055 & $(0.0049)$ & $0.23^{*}$ & $(0.089)$ \\
\hline Product safety/quality (PRO) & & & & & $-0.0080 * *$ & $(0.0030)$ & -0.045 & $(0.051)$ & 0.0040 & $(0.077)$ & 0.22 & $(1.10)$ & -0.0073 & $(0.0046)$ & -0.032 & $(0.057)$ \\
\hline Diversity (DIV) & & & & & 0.0041 & $(0.0056)$ & 0.030 & $(0.089)$ & -0.059 & $(0.11)$ & -0.21 & $(1.06)$ & 0.0050 & $(0.010)$ & 0.015 & $(0.11)$ \\
\hline Environment (ENV) & & & & & 0.0053 & $(0.0060)$ & -0.096 & $(0.11)$ & 0.031 & $(0.083)$ & 0.53 & $(0.85)$ & -0.0027 & $(0.0078)$ & -0.18 & $(0.12)$ \\
\hline Community (COM) & & & & & $-0.022 *$ & $(0.011)$ & 0.20 & $(0.17)$ & 0.042 & $(0.038)$ & $0.96^{*}$ & $(0.42)$ & -0.014 & $(0.018)$ & 0.15 & $(0.20)$ \\
\hline Interactions & & & & & & & & & & & & & & & & \\
\hline SI $x$ EMP & & & & & & & & & 0.017 & $(0.15)$ & -0.81 & $(1.35)$ & & & & \\
\hline SI $x$ PRO & & & & & & & & & -0.12 & $(0.11)$ & $-2.21 \dagger$ & $(1.21)$ & & & & \\
\hline SI x DIV & & & & & & & & & 0.044 & $(0.14)$ & 0.51 & $(1.36)$ & & & & \\
\hline SI x ENV & & & & & & & & & -0.18 & $(0.16)$ & -1.05 & $(1.62)$ & & & & \\
\hline SI x COM & & & & & & & & & -0.26 & $(0.26)$ & $-5.57^{*}$ & $(2.43)$ & & & & \\
\hline CE $x$ EMP & & & & & & & & & 0.00035 & $(0.00037)$ & $-0.019 * *$ & $(0.0049)$ & & & & \\
\hline CE $\times$ PRO & & & & & & & & & $-0.00077 \dagger$ & $(0.00040)$ & 0.0041 & $(0.0063)$ & & & & \\
\hline CE x DIV & & & & & & & & & 0.000021 & $(0.00067)$ & 0.0019 & $(0.0086)$ & & & & \\
\hline CE x ENV & & & & & & & & & -0.000054 & $(0.00053)$ & 0.0036 & $(0.0042)$ & & & & \\
\hline CE x COM & & & & & & & & & -0.0022 & $(0.0014)$ & -0.025 & $(0.018)$ & & & & \\
\hline EF x EMP & & & & & & & & & -0.0094 & $(0.11)$ & 0.17 & $(0.91)$ & & & & \\
\hline EF $x$ PRO & & & & & & & & & 0.00070 & $(0.091)$ & -0.17 & (1.31) & & & & \\
\hline EF x DIV & & & & & & & & & 0.064 & $(0.12)$ & 0.11 & (1.17) & & & & \\
\hline EF x ENV & & & & & & & & & -0.039 & $(0.095)$ & -1.10 & (1.11) & & & & \\
\hline $\mathrm{EF} \times \mathrm{COM}$ & & & & & & & & & - & & 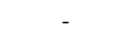 & & & & & \\
\hline CI $x$ EMP & & & & & & & & & -0.000019 & $(0.000020)$ & -0.00046 & $(0.00030)$ & & & & \\
\hline CI x PRO & & & & & & & & & $0.000043^{* *}$ & $(0.000014)$ & $0.00057 * *$ & $(0.00021)$ & & & & \\
\hline CI x DIV & & & & & & & & & $0.000055 \dagger$ & $(0.000028)$ & $0.00062 \dagger$ & $(0.00036)$ & & & & \\
\hline CI x ENV & & & & & & & & & $0.000088^{*}$ & $(0.000034)$ & $0.00094 *$ & $(0.00041)$ & & & & \\
\hline CI x COM & & & & & & & & & 0.000022 & $(0.000069)$ & 0.0013 & $(0.00095)$ & & & & \\
\hline Model statistics & & & & & & & & & & & & & & & & \\
\hline$F$ & & & & .3 & & 0.6 & 8 & 67 & . & & . & - & 1.09 & 1.09 & 2.27 & 2.27 \\
\hline Prob $>F$ & & & & 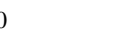 & & 0 & 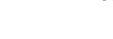 & 0 & 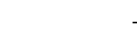 & & 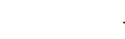 & 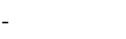 & 0.38 & 0.38 & 0.027 & 0.027 \\
\hline R2-within & & & & 20 & & .53 & & .22 & 0. & & 0. & 28 & 0.026 & 0.026 & 0.059 & 0.059 \\
\hline R2-between & & & & 015 & & .15 & 0.0 & 0044 & 0. & & 0.00 & 0020 & 0.027 & 0.027 & 0.095 & 0.095 \\
\hline$R 2$-overall & & & & 087 & & 13 & 0.0 & 0022 & 0. & & 0.0 & 040 & 0.031 & 0.031 & 0.064 & 0.064 \\
\hline Sigma_u & & & & 49 & & 098 & 1 & 42 & 0.0 & & 1. & 41 & 0.087 & 0.087 & 1.35 & 1.35 \\
\hline Sigma_e & & & & 64 & & 036 & 0 & 63 & 0.0 & & 0. & 62 & 0.051 & 0.051 & 0.69 & 0.69 \\
\hline Rho & & & & 84 & & .88 & 0 & 84 & 0.8 & & 0. & 84 & 0.75 & 0.75 & 0.79 & 0.79 \\
\hline
\end{tabular}

$\mathrm{N}=670$. Number of companies in the sample is 114 . Unstandardised regression coefficients are shown. Robust standard errors are in parentheses.

Table 8: Fixed-effects Panel Regression Results 


\begin{tabular}{|c|c|c|c|c|c|c|c|c|c|c|c|c|c|c|c|c|}
\hline \multirow{3}{*}{$\begin{array}{l}\text { Results of Fixed-Effects Panel Regressions } \\
\text { Dependent Variable } \\
\text { Constant }\end{array}$} & \multicolumn{4}{|c|}{ Airline } & \multicolumn{4}{|c|}{ Casino } & \multicolumn{4}{|c|}{ Hotel } & \multicolumn{4}{|c|}{ Restaurant } \\
\hline & \multicolumn{2}{|c|}{$\begin{array}{c}\text { (1) } \\
\text { ROA }\end{array}$} & \multicolumn{2}{|c|}{$\begin{array}{c}(2) \\
\text { Tobin's } Q\end{array}$} & \multicolumn{2}{|c|}{$\begin{array}{c}\text { (3) } \\
\text { ROA }\end{array}$} & \multicolumn{2}{|c|}{$\begin{array}{c}(4) \\
\text { Tobin's } Q\end{array}$} & \multicolumn{2}{|c|}{$\begin{array}{c}\text { (5) } \\
\text { ROA }\end{array}$} & \multicolumn{2}{|c|}{$\begin{array}{c}(6) \\
\text { Tobin's Q }\end{array}$} & \multicolumn{2}{|c|}{$\begin{array}{c}\text { (7) } \\
\text { ROA }\end{array}$} & \multicolumn{2}{|c|}{$\begin{array}{c}(8) \\
\text { Tobin's Q }\end{array}$} \\
\hline & $1.72 * *$ & $(0.36)$ & $4.16^{* * *}$ & $(1.18)$ & $0.76^{* * *}$ & $(0.13)$ & $6.92 * *$ & $(1.77)$ & $0.71 * *$ & $(0.11)$ & $9.45 * *$ & $(2.46)$ & $1.41^{* *}$ & $(0.16)$ & $14.4^{* * *}$ & $(2.29)$ \\
\hline \multicolumn{17}{|l|}{ Operating environment } \\
\hline Dynamism (DY) & $1.69^{*}$ & $(0.78)$ & $8.37^{*}$ & (3.49) & -0.21 & $(0.21)$ & -2.38 & (2.22) & -0.36 & $(0.42)$ & -7.76 & (12.0) & 0.32 & $(0.22)$ & $13.9^{* *}$ & (2.83) \\
\hline Munificence (MU) & $-0.19^{*}$ & $(0.087)$ & $-0.79^{*}$ & $(0.30)$ & 0.0034 & $(0.032)$ & -0.33 & $(0.46)$ & 0.016 & $(0.050)$ & $-2.88 *$ & (1.21) & -0.027 & $(0.018)$ & $-0.93^{*}$ & $(0.35)$ \\
\hline Power (PO) & $-1.23 \dagger$ & $(0.70)$ & $-10.5^{* *}$ & $(2.81)$ & $-8.47 *$ & (3.10) & 7.15 & (61.3) & 0.24 & (4.43) & $296 \dagger$ & (147) & 0.47 & (2.44) & 22.0 & (51.2) \\
\hline \multicolumn{17}{|l|}{ Strategy } \\
\hline Selling intensity (SI) & $-2.06 * *$ & $(0.63)$ & -3.81 & $(2.37)$ & $-1.18^{* *}$ & $(0.17)$ & $-10.1 * *$ & (2.19) & $-0.67 * *$ & $(0.090)$ & $-7.59 * *$ & (1.27) & $-1.66 * *$ & $(0.19)$ & $-11.8^{* *}$ & (2.43) \\
\hline Capital expenditure (CE) & $-0.0017 \dagger$ & $(0.00085)$ & 0.0083 & $(0.0090)$ & 0.00042 & $(0.00029)$ & $0.013 * *$ & $(0.0021)$ & $0.00068 * *$ & $(0.00013)$ & $0.012 * *$ & $(0.0032)$ & -0.00046 & $(0.00090)$ & 0.0064 & $(0.015)$ \\
\hline Cost efficiency (EF) & $-1.48 * *$ & $(0.27)$ & $-2.83^{*}$ & $(1.00)$ & $-0.71 * *$ & $(0.22)$ & -4.94 & $(3.14)$ & $-0.64 * *$ & $(0.17)$ & $-6.47 *$ & $(2.44)$ & $-1.42 * *$ & $(0.18)$ & $-12.9^{* *}$ & $(2.50)$ \\
\hline \multirow{2}{*}{\multicolumn{17}{|c|}{$\begin{array}{l}-0.00049 \\
\end{array}$}} \\
\hline & & & & & & & & & & & & & & & & \\
\hline Employees (EMP) & -0.12 & $(0.19)$ & -0.34 & $(0.94)$ & $0.20 *$ & $(0.071)$ & $3.86^{* *}$ & $(0.68)$ & 0.095 & $(0.072)$ & $6.51^{*}$ & (2.64) & -0.023 & $(0.052)$ & -0.80 & $(0.76)$ \\
\hline Product safety/quality (PRO) & 0.21 & $(0.21)$ & 0.38 & $(2.01)$ & 0.095 & $(0.096)$ & 1.90 & (1.26) & 0.026 & $(0.13)$ & $4.33 \dagger$ & $(2.46)$ & $0.15 \dagger$ & $(0.083)$ & 0.55 & (1.54) \\
\hline Diversity (DIV) & $-0.56^{*}$ & $(0.23)$ & $-3.29 \dagger$ & (1.81) & o & & o & & -0.00040 & $(0.26)$ & 4.25 & $(5.77)$ & 0.025 & $(0.095)$ & 2.65 & (1.61) \\
\hline Environment (ENV) & -0.16 & $(0.36)$ & 3.03 & (1.93) & o & & o & & 0.079 & $(0.15)$ & 2.47 & $(2.36)$ & $0.81^{* *}$ & $(0.17)$ & $5.44 *$ & (2.71) \\
\hline Community (COM) & o & & o & & o & & o & & & & & & o & & o & \\
\hline Interactions & ( & & & & & & & & o & & o & & & & & \\
\hline SI x EMP & 0.56 & $(0.62)$ & 0.51 & (3.22) & $-0.49 * *$ & $(0.11)$ & $-8.82 * *$ & (1.45) & $-0.17 * *$ & $(0.040)$ & $-9.90 *$ & (3.91) & 0.021 & $(0.15)$ & -3.20 & (3.15) \\
\hline SI x PRO & -0.38 & $(0.26)$ & -0.78 & $(2.00)$ & $-0.32 \dagger$ & $(0.16)$ & $-5.20^{*}$ & (2.19) & 0.081 & $(0.17)$ & -4.57 & (3.04) & -0.51 & $(0.30)$ & 3.14 & (4.98) \\
\hline SI x DIV & -1.38 & $(0.83)$ & -6.18 & (5.93) & o & & o & & -0.079 & $(0.27)$ & -7.64 & (5.44) & -0.032 & $(0.11)$ & -2.41 & (1.92) \\
\hline SI x ENV & 0.22 & $(0.30)$ & -2.50 & (2.77) & o & & o & & -0.17 & $(0.19)$ & $-5.47 \dagger$ & (3.07) & $-1.71 * *$ & $(0.41)$ & -1.49 & (5.05) \\
\hline SI x COM & o & & o & & o & & o & & o & & o & & o & & o & \\
\hline CE x EMP & -0.0011 & $(0.00087)$ & -0.0084 & $(0.0093)$ & 0.00035 & $(0.00030)$ & $-0.027^{* *}$ & $(0.0028)$ & -0.00068 & $(0.00074)$ & $-0.053^{*}$ & $(0.024)$ & -0.00066 & (0.00095) & 0.0060 & (0.024) \\
\hline CE $x$ PRO & -0.0017 & $(0.0015)$ & -0.00053 & $(0.015)$ & 0.00050 & $(0.00044)$ & 0.00071 & $(0.011)$ & $0.00098 \dagger$ & $(0.00050)$ & $0.071 *$ & $(0.025)$ & -0.00038 & $(0.0014)$ & 0.028 & $(0.031)$ \\
\hline CE x DIV & 0.0021 & $(0.0016)$ & 0.011 & (0.0078) & o & & o & & -0.0014 & $(0.0020)$ & 0.00042 & $(0.033)$ & $0.0033^{*}$ & $(0.0016)$ & 0.0084 & $(0.023)$ \\
\hline CE x ENV & 0.0017 & $(0.0027)$ & $0.032 *$ & $(0.013)$ & 0.015 & $(0.014)$ & -0.090 & $(0.29)$ & -0.00024 & $(0.00077)$ & 0.0032 & $(0.011)$ & $-0.0032 *$ & $(0.0015)$ & -0.012 & (0.034) \\
\hline CE x COM & o & & o & & $-0.0034 *$ & $(0.0013)$ & $-0.097 * *$ & $(0.029)$ & o & & o & & o & & o & \\
\hline EF x EMP & -0.033 & $(0.17)$ & 0.25 & $(0.61)$ & $-0.14 *$ & $(0.053)$ & $-2.77 * *$ & $(0.83)$ & -0.10 & $(0.082)$ & $-7.29 *$ & (2.99) & 0.048 & $(0.058)$ & $1.92 *$ & $(0.79)$ \\
\hline EF x PRO & -0.23 & $(0.23)$ & -0.13 & (2.16) & -0.013 & $(0.11)$ & -0.48 & (1.35) & -0.055 & $(0.14)$ & $-5.52 \dagger$ & $(2.71)$ & $-0.14 \dagger$ & $(0.082)$ & -1.38 & (1.65) \\
\hline EF x DIV & $0.47 *$ & $(0.21)$ & $2.49 \dagger$ & (1.36) & o & & o & & 0.0035 & $(0.30)$ & -5.64 & $(6.86)$ & -0.061 & $(0.098)$ & $-3.22 \dagger$ & (1.77) \\
\hline EF x ENV & 0.17 & $(0.36)$ & $-4.74 *$ & (1.72) & o & & o & & -0.071 & $(0.17)$ & -2.46 & (2.66) & $-0.76^{* *}$ & $(0.16)$ & $-6.52^{*}$ & (2.65) \\
\hline EF x COM & o & & o & & o & & o & & o & & o & & o & & o & \\
\hline CI x EMP & 0.00018 & $(0.00011)$ & 0.00059 & $(0.00041)$ & -0.000092 & $(0.000068)$ & $-0.00092 *$ & $(0.00044)$ & 0.000013 & $(0.00011)$ & 0.00100 & $(0.0013)$ & $-0.00018^{* *}$ & $(0.000050)$ & $-0.0013 \dagger$ & $(0.00067)$ \\
\hline CI x PRO & 0.000047 & $(0.00011)$ & -0.00061 & $(0.00060)$ & $-0.00012^{*}$ & $(0.000047)$ & $-0.0014 \dagger$ & $(0.00070)$ & -0.000054 & $(0.000057)$ & $-0.0033 \dagger$ & $(0.0017)$ & 0.000021 & $(0.000023)$ & -0.00028 & $(0.00037)$ \\
\hline CI x DIV & $0.00080 \dagger$ & $(0.00042)$ & $0.0051 \dagger$ & $(0.0026)$ & 0.000054 & $(0.000074)$ & -0.0011 & $(0.0013)$ & 0.000096 & $(0.00020)$ & 0.0020 & $(0.0029)$ & $-3.4 \mathrm{e}-06$ & $(0.000013)$ & -0.00025 & $(0.00023)$ \\
\hline CI x ENV & $-3.5 \mathrm{e}-06$ & $(0.00016)$ & 0.0014 & $(0.0011)$ & 0.00079 & $(0.00047)$ & 0.010 & $(0.0063)$ & $7.2 \mathrm{e}-06$ & $(0.00011)$ & -0.00084 & $(0.0018)$ & $-0.0020 * *$ & $(0.00047)$ & $-0.018^{*}$ & $(0.0081)$ \\
\hline CI x COM & o & & o & & 0.000076 & $(0.000068)$ & $0.0044^{* *}$ & $(0.0012)$ & o & & o & & $-0.00047 * *$ & $(0.00018)$ & $-0.0052 * *$ & $(0.0018)$ \\
\hline \multicolumn{17}{|l|}{ Model statistics } \\
\hline$N$ & \multirow{2}{*}{\multicolumn{2}{|c|}{$\begin{array}{c}100 \\
17\end{array}$}} & & 00 & & 40 & 14 & & 11 & & $11 \mathrm{c}$ & & 31 & & & 14 \\
\hline Number of Companies & & & & 17 & & 22 & 22 & & 2 & & 21 & & 54 & & 5 & 44 \\
\hline$R 2$-between & 0.1 & & & 16 & 0.0 & 086 & 0.0 & & 0.00 & & 0.01 & & 0.3 & & 0.0 & 060 \\
\hline Sigma_u & 0.1 & & & 59 & 0. & 17 & 2.4 & & 0.1 & & 1.9 & & 0.0 & & & 41 \\
\hline Sigma_ $_{-}$ & 0.03 & & & 26 & & 030 & 0.5 & & 0.0 & & 0.5 & & 0.0 & & & 64 \\
\hline Rho & 0.9 & & & 84 & & 97 & 0.9 & & 0.9 & & 0.9 & & 0.9 & & & 83 \\
\hline
\end{tabular}

Unstandardised regression coefficients are shown. Robust standard errors are in parentheses. o: omitted because of collinearity.

Table 9: Results of the Fixed-effects Panel Regressions for Model 2 for the Various Industries 
Hypothesis 2 is supported for the tourism sector analysis shown in Table 8, Model 2. The hypothesis states that a firm's strategy variables have a direct effect on CFP, which is moderated by stakeholder management, represented as CSR variables. This is true for both ROA and Tobin's Q, although the support is stronger for the long term. Specifically, for Tobin's Q, we find a significant positive direct effect with community activities, and for the moderations, for example, a positive effect between the capital intensity and environmental performance and diversity activities, and a negative effect between the selling intensity and community activities, among others. For ROA, we find no support for the direct effects but we find positive effects for the moderations, such as between the capital intensity with product, diversity and environmental performance activities.

Moreover, we also appreciate that the effects of the strategy and CSR variables, and their interactions, especially between the selling intensity and community activities, have a greater impact on long-term financial performance. Taken together with the results for Hypothesis 1, we can see that the environmental performance and diversity activities became significant both in the short and long terms through their moderation with strategy variables.

Overall, one can argue that the firm's strategic decisions are moderated by the different types of stakeholder interest, and that the moderated effects are stronger in the long term. This can be explained by the fact that activities that aim to improve products and diversity, or activities with the community, employees or the environment, tend to have a limited impact in the short term; however, they amount to a greater significant effect in the long term. Finally, in relation to Hypothesis 2, our results are not directly comparable with other moderated models, such as Lee, Seo et al. (2013) and Lee, Singal et al. (2013), given that the set of moderation variables is different and that they examine specific industries rather than the sector overall.

Hypothesis 3 is not supported for the tourism sector analysis, as shown in Table 8, Model 3. Similarly to Berman et al. (1999), the results show that commitment to CSR does not mediate the relationship between firm strategy and CFP, either for the short term or the long term, after the impact of the operating environment is controlled for. Specifically, for ROA, two CSR variables that are not significant in Model 3 become significant in Model $1 \mathrm{~b}$, for example, community and product, whereas for Tobin's $\mathrm{Q}$, the employee activities 
remain significant and positive for both models. The intrinsic stakeholder commitment model (Model 3) shown in Figure 1 assumes that firms establish certain moral principles and take appropriate CSR actions because of established normative commitments towards their stakeholders. It seems that, based on the empirical results, the relationship between CFP, CSR and strategy variables is instrumental and not normative, which suggests that the emphasis placed on strategy in the tourism sector is driven by the long-term market valuation, rather than by moral or ethical principles.

In relation to the tourism sector overall, Hypothesis 2 is supported for each of the four industries. As shown in Table 9, all CSR dimensions, with the exception of the community activities, affect the two financial performance measures differently. The same applies for the effects of the interactions. In terms of effect sizes in absolute terms, and when considering each industry separately, it is possible to appreciate that the effects of the CSR and strategy variables, and their interactions, have a greater impact on long-term financial performance.

Overall, the results indicate that the financial direct effects of the various CSR dimensions are different for firms in different industries based on the level of importance assigned to each stakeholder's interest. This is in line with previous studies that examined tourismrelated industries (Inoue \& Lee 2011; Kang et al. 2010; Kim \& Kim 2014; Youn et al. 2015). The results also indicate the moderating effects of CSR on the various strategy dimensions, supporting the instrumental perspective, which is also in line with previous research for other sectors (Berman et al. 1999; Coles et al. 2013; Dabic et al. 2016). Furthermore, in line with Berman et al. (1999), we found no support for the intrinsic stakeholder commitment model (Model 3), that is, for the normative perspective.

In particular, our results show that for airlines, the diversity activities have a negative effect on financial performance in both the short and long terms; however, this is counterbalanced by the effect of strategy variables such as cost efficiency and capital intensity. This result differs from previous studies that examined the same industry (Inoue \& Lee, 2011; Lee, Seo, et al., 2013), which may be a result of differences in the data set and model specification. For casinos, the employee relation activities positively affect financial performance in both the short and long terms. In contrast, previous studies found no such support (Inoue \& Lee 2011). Furthermore, these effects are offset by strategic variables, such as selling intensity, cost efficiency and capital expenditure. For hotels, we find positive effects on long-term financial performance in relation to the employee relations 
and product activities, which are moderated by strategic variables, including selling intensity, cost efficiency and capital expenditure. This result is consistent with previous studies that used a direct effects model in relation to the product activities (Inoue \& Lee 2011). Finally, for restaurants, the environmental performance activities positively affect financial performance in both the short and long terms. However, these effects are moderated in the short term by all the strategic variables, and in the long term by cost efficiency and capital intensity. This result is different from previous studies that used a direct effects model (Inoue \& Lee, 2011; Lee, Singal et al., 2013) ,which might be due to data set and model specification differences.

Overall, the results for the different industries suggest that managers should not only pay attention to the direct effects of CSR dimensions on CFP but also consider the possible indirect effects of CSR via modifications of the impact of strategic variables, and, more importantly, that these effects are much larger in the long term than the short term.

\section{Conclusions}

The purpose of this paper is to advance the theoretical and empirical research examining the relationship between CSR and CFP in tourism-related industries by providing a theoretical foundation based on stakeholder theory. We began by discussing the two theoretical approaches to a firm's stakeholder orientation, the strategic stakeholder model and the intrinsic stakeholder commitment model. We then evaluated the descriptive accuracy of the proposed models for the sector and for four tourism-related industries: airlines, casinos, hotels and restaurants. The results of the longitudinal investigation provide support for the instrumental perspective but not the normative perspective, similarly to previous studies in the manufacturing sector. The results give us useful insights into the way that stakeholder management practices, expressed as CSR activities, interact with firm strategy and CFP for each of the four industries. Thus, managers of tourismrelated industries, and other tourism-related stakeholders at large, should be aware of the role of the social and environmental activities of firms, and how activities relating to employees, products, community, diversity and the environment create market value for the firm and other forms of value for society.

Moreover, the study used robust methodological artefacts and data that are available in external databases, so that it is both replicable and comparable with related studies 
(Hartshorne \& Schachner 2012). In this respect, our work contributes to the field of investigation in two ways. First, by describing a study that can be replicated and checked for the accuracy of its findings by anyone interested in this area. Second, by proving the opportunity to compare our data sets and methodological artefacts with other studies, identifying gaps and opportunities for further research and, thus, improving the quality of the published research.

Despite the sound contributions, this study has some limitations, which could also provide directions for future research. First, regardless of the wide use of the MSCI ESG data set in the existing literature, it is still limited in terms of the sample of firms included and might suffer from an inaccurate weight problem due to its evaluation practice of assigning a binary value to each CSR dimension (McWilliams \& Siegel 2001; Inoue \& Lee 2011). Second, the MSCI ESG data set has evolved over the years and variables have been modified, added or removed (MSCI 2015b). Furthermore, firms have merged and acquired and these changes have not been considered in the data set. Thus, the set of CSR variables used in this study has been limited to those that have been measured over the study period and does not consider changes such as mergers and acquisitions. Furthermore, previous studies that have used the MSCI ESG data set for different time periods had access to a different set of variables, which implies that the results between studies are not directly comparable. Finally, while it is not possible to address the limitations of the MSCI EFG data set itself, future research could consider expanding the number of companies considered by obtaining data from other sources such as the Carbon Disclosure Project (CDP 2016).

The strategy dimensions used in this study are based on previous literature that relates to the goods industries (Hambrick 1983). Although the results from the study indicate that CSR moderates the relationship between strategy and CFP, it is possible that, for service industries, it might also be appropriate to consider other strategy dimensions.

Another possible limitation is the rather narrow definition of financial performance using ROA for the short-term, and Tobin's Q for the long-term, perspective. Previous research has argued for an expansion of the definition of financial performance to include additional measures (Berman et al., 1999; Leonidou et al., 2013; Lee, Singal et al., 2013). A more inclusive measure of financial performance might enhance the normative elements of the stakeholder theory and also help to revisit the validity of the intrinsic stakeholder commitment model by allowing a better understanding of the important links among 
stakeholder relationships, firm strategy and financial performance (Berman et al. 1999). Furthermore, a future avenue for research might consider a broader definition of performance measures - not just financial - that includes current and emerging business trends in the tourism sector, such as cost-efficiency, competitiveness and productivity (Sainaghi et al. 2017).

Finally, it might be necessary to broaden the scope of the proposed theoretical framework to consider other moderator and control variables that have been explored in the previous literature. Examples of moderator variables considered previously include firm-level variables (Lee, Seo et al., 2013; Youn et al., 2015) or industry-level variables (Lee, Singal et al., 2013; Leonidou et al., 2013). Similarly, examples of control variables used previously include firm size (Inoue \& Lee, 2011; Lee \& Park, 2009b), leverage (Inoue \& Lee 2011; Kang et al. 2010), systematic risk (Lee, Singal et al., 2013), DIV (Lee, Seo et al., 2013) and stock performance (Singal 2014), among others. 


\section{References}

Albertini, E., 2013. Does environmental management improve financial performance? A meta-analytical review. Organization \& Environment, 26(4), pp.431-457.

Allouche, J. \& Laroche, P., 2005. A meta-analytical investigation of the relationship between corporate social and financial performance. Revue de gestion des ressources humaines, 57, pp.18-41.

Ambec, S. \& Lanoie, P., 2008. Does it pay to be green? A systematic overview. Academy of Management Perspectives, 22(4), pp.45-62.

Berman, S.L. et al., 1999. Does stakeholder orientation matter? The relationship between stakeholder management models and firm financial performance. Academy of Management Journal, 42(5), pp.488-506.

Busch, T. \& Hoffmann, V.H., 2011. How hot is your bottom line? Linking carbon and financial performance. Business \& Society, 50(2), pp.233-265.

Carmona-Moreno, E., Céspedes-Lorente, J. \& De Burgos-Jiménez, J., 2004. Environmental strategies in spanish hotels: contextual factors and performance. The Service Industries Journal, 24(3), pp.101-130.

CDP, 2016. Carbon Disclosure Project. Available at: http://www.cdp.net [Accessed March 14, 2017].

Clarkson, M., 1995. A stakeholder framework for analyzing and evaluating corpora. Academy of Management Review, 20(1), pp.92-117.

Claver-Cortés, E. et al., 2007. Environmental strategies and their impact on hotel performance. Journal of Sustainable Tourism, 15(6), pp.663-679.

Coles, T., Fenclova, E. \& Dinan, C., 2013. Tourism and corporate social responsibility: A critical review and research agenda. Tourism Management Perspectives, 6, pp.122-141.

Dabic, M. et al., 2016. Industry-specific CSR: analysis of 20 years of research. European Business Review, 28(3), pp.250-273.

Dixon-Fowler, H. et al., 2013. Beyond "Does it pay to be green?" A meta-analysis of 
moderators of the CEP-CFP relationship. Journal of Business Ethics, 112(2), pp.353366.

Donaldson, T. \& Preston, L.E., 1995. The stakeholder theory of the corporation: concepts, evidence, and implications. Academy of Management Review, 20(1), pp.65-91.

Endrikat, J., Guenther, E. \& Hoppe, H., 2014. Making sense of conflicting empirical findings: A meta-analytic review of the relationship between corporate environmental and financial performance. European Management Journal, 32(5), pp.735-751.

European Commission, 2011. A renewed EU strategy 2011-14 for Corporate Social Responsibility. Available ht: ht//eurlex.europa.eu/LexUriServ/LexUriServ.do?uri=COM:2011:0681:FIN:en:PDF [Accessed March 14, 2017].

Falck, O. \& Heblich, S., 2007. Corporate social responsibility: Doing well by doing good. Business Horizons, 50(3), pp.247-254.

Freeman, R.E., 2000. Business ethics at the millennium. Business Ethics Quarterly, 10(1), pp.169-180.

Freeman, R.E., 1984. Strategic management: A stakeholder approach, Boston: Pitman.

Garay, L. \& Font, X., 2012. Doing good to do well? Corporate social responsibility reasons, practices and impacts in small and medium accommodation enterprises. International Journal of Hospitality Management, 31(2), pp.329-337.

Godfrey, P.C. \& Hatch, N.W., 2007. Researching corporate social responsibility: An agenda for the 21st century. Journal of Business Ethics, 70(1), pp.87-98.

Griffin, J. \& Mahon, J., 1997. The corporate social performance and corporate financial performance debate: Twenty-five years of incomparable research. Business \& Society, 36(1), pp.5-31.

Hambrick, D.C., 1983. High profit strategies in mature capital goods industries: A contingency approach. Academy of Management Journal, 26(4), pp.687-707.

Hartshorne, J.K. \& Schachner, A., 2012. Tracking replicability as a method of postpublication open evaluation. Frontiers in Computational Neuroscience, 6(8), pp.1-14. 
Inoue, Y. \& Lee, S., 2011. Effects of different dimensions of corporate social responsibility on corporate financial performance in tourism-related industries. Tourism Management, 32(4), pp.790-804.

Jauch, L.K. \& Kraft, K.L., 1986. Strategic management of uncertainty. Academy of Management Review, 11(4), pp.777-790.

Kang, K., Lee, S. \& Huh, C., 2010. Impacts of positive and negative corporate social responsibility activities on company performance in the hospitality industry. International Journal of Hospitality Management, 29(1), pp.72-82.

Kim, M. \& Kim, Y., 2014. Corporate social responsibility and shareholder value of restaurant firms. International Journal of Hospitality Management, 40, pp.120-129.

Kirk, D., 1995. Environmental management in hotels. International Journal of Contemporary Hospitality Management, 7(6), pp.3-8.

Laplume, A.O., Sonpar, K. \& Litz, R.A., 2008. Stakeholder theory: Reviewing a theory that moves us. Journal of Management, 34(6), pp.1152-1189.

Lee, M., 2008. A review of the theories of corporate social responsibility: Its evolutionary path and the road ahead. International Journal of Management Reviews, 10(1), pp.53-73.

Lee, S. \& Park, S., 2009a. Do socially responsible activities help hotels and casinos achieve their financial goals? International Journal of Hospitality Management, 28(1), pp.105112.

Lee, S. \& Park, S., 2009b. Financial impacts of socially responsible activities on asirline companies. Journal of Hospitality \& Tourism Research, 34(2), pp.185-203.

Lee, S., Seo, K. \& Sharma, A., 2013. Corporate social responsibility and firm performance in the airline industry: The moderating role of oil prices. Tourism Management, 38, pp.2030.

Lee, S., Singal, M. \& Kang, K., 2013. The corporate social responsibility-financial performance link in the U.S. restaurant industry: Do economic conditions matter? International Journal of Hospitality Management, 32, pp.2-10.

Leiper, N., 1979. The framework of tourism. Annals of Tourism Research, 6(4), pp.390-407. 
Leonidou, L.C. et al., 2013. Resources and capabilities as drivers of hotel environmental marketing strategy: Implications for competitive advantage and performance. Tourism Management, 35, pp.94-110.

Margolis, J.D., Elfenbein, H.A. \& Walsh, J.P., 2009. Does it pay to be good...and does it matter? A meta-analysis of the relationship between corporate social and financial performance. SSRN Electronic Journal, pp.1-68. Available at: https://ssrn.com/abstract=1866371.

McWilliams, A. \& Siegel, D., 2001. Corporate social responsibility: a theory of the firm perspective. Academy of Management Review, 26(1), pp.117-127.

Mohammed, I., Denizci Guillet, B. \& Law, R., 2015. The contributions of economics to hospitality literature: A content analysis of hospitality and tourism journals. International Journal of Hospitality Management, 44, pp.99-110.

Molina-Azorin, J.F. et al., 2009. Environmental practices and firm performance: An empirical analysis in the Spanish hotel industry. Journal of Cleaner Production, 17(5), pp.516524.

MSCI, 2015a. ESG ratings. Available at: https://www.msci.com/esg-ratings [Accessed March 14, 2017].

MSCI, 2015b. ESG Ratings Methodology. Available at: https://www.msci.com/www/research-paper/esg-ratings-methodology/0175943017 [Accessed March 14, 2017].

Nicolau, J.L., 2008. Corporate social responsibility. Annals of Tourism Research, 35(4), pp.990-1006.

Orlitzky, M., Schmidt, F. \& Rynes, S., 2003. Corporate social and financial performance: A meta-analysis. Organization Studies, 24, pp.403-441.

Park, S.-Y. \& Lee, S., 2009. Financial rewards for social responsibility: A mixed picture for restaurant companies. Cornell Hospitality Quarterly, 50(2), pp.168-179.

Phillips, P. \& Moutinho, L., 2014. Critical review of strategic planning research in hospitality and tourism. Annals of Tourism Research, 48, pp.96-120. 
Phillips, R. \& Reichart, J., 2000. The environment as a stakeholder? A fairness-based approach. Journal of Business Ethics, 23(2), pp.185-197.

Rodriguez, F. \& Cruz, Y., 2007. Relation between social-environmental responsibility and performance in hotel firms. International Journal of Hospitality Management, 26(4), pp.824-839.

Rowley, T. \& Berman, S., 2000. A brand new brand of corporate social performance. Business \& Society, 39(4), pp.397-418.

Russo, M. V. \& Fouts, P.A., 1997. A resource-based perspective on corporate environmental performance and profitability. Academy of Management Journal, 40(3), pp.534-559.

Sainaghi, R., Phillips, P. \& Zavarrone, E., 2017. Performance measurement in tourism firms: A content analytical meta-approach. Tourism Management, 59, pp.36-56.

Sharma, S. \& Henriques, I., 2005. Stakeholder influences on sustainability practices in the Canadian forest products industry. Strategic Management Journal, 26(2), pp.159-180.

Singal, M., 2014. Corporate social responsibility in the hospitality and tourism industry: Do family control and financial condition matter? International Journal of Hospitality Management, 36, pp.81-89.

Weston, J.F. \& Chung, K.S., 1990. Takeovers and corporate restructuring: An overview. Business Economics, 25(2), pp.6-11.

Wood, D.J., 1991. Corporate social performance revisited. Academy of Management Review, 16(4), pp.691-718.

Youn, H., Hua, N. \& Lee, S., 2015. Does size matter? Corporate social responsibility and firm performance in the restaurant industry. International Journal of Hospitality Management, 51, pp.127-134. 